NBER WORKING PAPER SERIES

\title{
SHORT-TERM PAIN FOR LONG-TERM GAIN: MARKET DEREGULATION AND MONETARY POLICY IN SMALL OPEN ECONOMIES
}

\author{
Matteo Cacciatore \\ Romain Duval \\ Giuseppe Fiori \\ Fabio Ghironi \\ Working Paper 21784 \\ http://www.nber.org/papers/w21784 \\ NATIONAL BUREAU OF ECONOMIC RESEARCH \\ 1050 Massachusetts Avenue \\ Cambridge, MA 02138 \\ December 2015
}

\begin{abstract}
Presented at the JIMF-SNB-BIS-Dallas Fed-CEPR Conference on "Spillovers of Conventional and Unconventional Monetary Policy: The Role of Real and Financial Linkages," Zurich, July 9-10, 2015. For very helpful comments, we thank our discussant, Giancarlo Corsetti, as well as Raphael Auer, an anonymous referee, and the conference participants. We are also grateful to Orsetta Causa, Jorgen Elmeskov, and Jean-Luc Schneider. Errors and omissions are our responsibility. An earlier version of this paper was circulated under the title "Short-Term Gain or Pain? A DSGE Model-Based Analysis of the Short-Term Effects of Structural Reforms in Labour and Product Markets" (OECD Economics Department Working Paper 948), and much work on this paper was done while Duval was affiliated with the OECD. The views in this paper are those of the authors and do not represent the views or policies of the CEPR, IMF, NBER, and OECD.
\end{abstract}

NBER working papers are circulated for discussion and comment purposes. They have not been peerreviewed or been subject to the review by the NBER Board of Directors that accompanies official NBER publications.

(C) 2015 by Matteo Cacciatore, Romain Duval, Giuseppe Fiori, and Fabio Ghironi. All rights reserved. Short sections of text, not to exceed two paragraphs, may be quoted without explicit permission provided that full credit, including () notice, is given to the source. 
Short-Term Pain for Long-Term Gain: Market Deregulation and Monetary Policy in Small Open Economies

Matteo Cacciatore, Romain Duval, Giuseppe Fiori, and Fabio Ghironi

NBER Working Paper No. 21784

December 2015

JEL No. E24,E32,E52,F41,J64,L51

\section{ABSTRACT}

This paper explores the effects of labor and product market reforms in a New Keynesian, small open economy model with labor market frictions and endogenous producer entry. We show that it takes time for reforms to pay off, typically at least a couple of years. This is partly because the benefits materialize through firm entry and increased hiring, both of which are gradual processes, while any reform-driven layoffs are immediate. Some reforms-such as reductions in employment protection-increase unemployment temporarily. Implementing a broad package of labor and product market reforms minimizes transition costs. Importantly, reforms do not have noticeable deflationary effects, suggesting that the inability of monetary policy to deliver large interest rate cuts in their aftermath-either because of the zero bound on policy rates or because of membership in a monetary union-may not be a relevant obstacle to reform. Alternative simple monetary policy rules do not have a large effect on transition costs.

Matteo Cacciatore

HEC Montréal

Institute of Applied Economics

3000 chemin de la Côte-Sainte-Catherine

Montréal (Québec), Canada H3T 2A7

matteo.cacciatore@hec.ca

Romain Duval

Research Department

International Monetary Fund

70019 th Street, N.W.

Washington, D.C. 20431, U.S.A.

rduval@imf.org

\author{
Giuseppe Fiori \\ North Carolina State University \\ Poole School of Management \\ Department of Economics \\ 2801 Founders Dr, Box 8110 \\ Raleigh (NC), 27695-8110 \\ giuseppefiori@gmail.com \\ Fabio Ghironi \\ Department of Economics \\ University of Washington \\ Savery Hall, Box 353330 \\ Seattle, WA 98195 \\ and NBER \\ ghiro@uw.edu
}




\section{Introduction}

Calls for market reforms to improve economic performance have become a mantra in policy discussions. One only needs to read the transcripts of ECB President Mario Draghi's speeches and press conferences over the last three years or the statements of other European policymakers to substantiate the point. Structural reforms appear to have become a crucial ingredient of the policy menu at a time when the conventional tools of demand-side macroeconomic policy are constrained and unconventional tools are being deployed without certainty of their effectiveness. In the academic literature, a large body of economic theory points to long-term gains from reforms designed to increase the flexibility of labor and product markets. However, most of this literature provides insights into the long-term impact of such structural reforms from a static perspective. ${ }^{1}$ Much less consensus exists on the short-run effects and transition dynamics triggered by changes in product and labor market regulation, leaving the issue of whether market reforms imply trading short-term pain for long-term gains largely unsettled. Yet this issue bears major implications for the political feasibility of reforms, as transition costs may be viewed by policymakers called upon to implement reforms as a daunting obstacle to action.

The nature of the short- and medium-term impact of reforms also matters for their desirability in the context in which they are advocated now - where traditional, demand-side macroeconomic policy cannot be used to smooth potential short-run costs and help front-load beneficial long-run effects. This issue is especially relevant at the current juncture, with monetary policies constrained by the zero lower bound (ZLB) on interest rates and/or monetary union membership, and fiscal policies tied by austerity requirements. With respect to monetary policy, a debate has emerged recently in the literature as to whether a binding ZLB could exacerbate potential short-run costs of reforms. According to this argument, in a ZLB situation, reform-driven shocks to current output supply may lower prices, raise the real interest rate, and thereby depress rather than stimulate the economy (a situation labelled the "paradox of toil" in Eggertsson, 2010). Eggertsson, Ferrero, and Raffo (2014) build on this argument in their analysis of structural reforms and monetary policy in Europe. On the other hand, market reforms may generate a positive wealth effect on consumption by increasing future income levels, and thereby stimulate current aggregate demand and output. When the ZLB is binding, this wealth effect should typically be larger as it is not dampened by the increase in interest rates that would occur in "normal times" (Fernández-Villaverde, Guerrón-

\footnotetext{
${ }^{1}$ For instance, this is the approach in an influential paper by Blanchard and Giavazzi (2003).
} 
Quintana, and Rubio-Ramírez, 2011). Ultimately, the short-term impact of reforms, not only in a ZLB situation but also more broadly, will depend inter alia on their impact on current versus future supply and the implications for output gaps, prices, and real interest rates.

A number of recent papers have used large-scale dynamic stochastic general equilibrium (DSGE) models to assess both the short- and long-run effects of reforms (Everaert and Schule, 2008, using the IMF's Global Economy Model; Gomes et al., 2010, using the ECB's EAGLE model; Hobza and Mourre, 2010, and Arpaia et al., 2007, using the European Commission's QUEST model). Reforms appear to pay off only gradually - it typically takes several years for half of the long-term effects to materialize, depending on the model and the reform considered-and can even entail short-run losses due to adverse demand or terms-of-trade effects. However, these exercises differ with respect to which of labor or product market reforms are more likely to lead to short-term losses. Labor market reforms are generally modeled to weaken the bargaining position of workers and thereby initially reduce real wages. This stimulates labor demand but at the same time can weaken consumer demand, especially if - as in an individual country within a monetary unionmonetary policy cannot react. Product market reforms are treated as reductions in price markups that immediately raise real wages, and quickly stimulate output and employment - although some of the associated income gain may be dampened by a decline in terms of trade associated with increased supply of domestic goods. However, if carried out in a monetary union or if implemented gradually, inducing households to expect lower prices in the future, they may raise the domestic real interest rate and thereby reduce short-term consumption and output. ${ }^{2}$

This paper studies the dynamic effects of labor and product market reforms in a DSGE, New Keynesian small open economy model that addresses two main weaknesses of the existing literature: (i) Structural reforms of product and labor markets are modeled in a very stylized - "reducedform" - way, as exogenous reductions in price and wage markups; and (ii) the models are not ideally suited to capture the full range of dynamic effects of structural reforms as both firm and labor market (hiring-firing) dynamics are absent. We address these shortcomings by modeling labor and product market dynamics and the policy factors that drive them, building on the framework developed by Cacciatore and Fiori (forthcoming). Our model integrates two leading frameworks developed to study product and labor market dynamics: Endogenous variation of monopolistically competitive producers subject to sunk entry costs builds on Bilbiie, Ghironi, and Melitz (2012),

\footnotetext{
${ }^{2}$ For empirical analysis of the effects of structural reforms based on the main policy changes implemented across OECD countries over the last three decades, see Bouis et al. (2012).
} 
while labor markets are characterized by search-and-matching frictions, with endogenous job creation and destruction, as in Diamond (1982a,b), Mortensen and Pissarides (1994), and den Haan, Ramey, and Watson (2000). Nominal rigidity implies that the monetary policy regime matters for the short-term consequences of market reforms. Deregulation of the product market reduces sunk producer entry costs (by cutting "red tape"). Deregulation of labor markets lowers unemployment benefits and employment protection (worker bargaining power and firing costs). We focus on a small open economy scenario to capture the situation of weak Euro Area countries for which such market reforms have been advocated to improve economic performance. In so doing, we contribute to the debate on non-conventional policy instruments to boost economies out of persistent weakness. ${ }^{3}$ A contribution of this paper relative to the existing literature is to consider a wider menu of possible market reforms.

We find that product market and labor market reforms have positive effects on and consumption, and also reduce unemployment, in the long run. ${ }^{4}$ However, it takes time for reforms to pay off in terms of aggregate consumption and employment, typically at least a couple of years, consistent with studies referred to above. This is partly because the benefits of reforms materialize through firm entry or increased hiring, both of which are gradual processes, while any reform-driven layoffs are immediate. The gains from product market reforms accrue more slowly than those from labor market reforms, although they are also typically larger.

Some reforms can entail transition costs, temporarily increasing unemployment-typically for one to two years. In particular, employment protection reform initially increases layoffs more than it creates jobs, and product market reform can also temporarily lead to net job destruction as incumbent firms downsize, and reallocation of laid-off workers takes time. By contrast, cuts in unemployment benefits or strengthening of activation policies (improvement of matching efficiency in the labor market) quickly reduce unemployment as they stimulate hiring without affecting firing. ${ }^{5}$

\footnotetext{
${ }^{3}$ Andrés, Arce, and Thomas (2014) explore the role of structural reforms as an instrument to push economies out of recession in the presence of debt deleveraging. Following Eggertsson, Ferrero, and Raffo (2014), they model reforms as exogenous reductions in price and wage markups. Cacciatore, Fiori, and Ghironi (forthcoming, a) use a model with product and labor market dynamics to study the consequences of market reforms for optimal monetary policy in a two-country monetary union, and Cacciatore, Fiori, and Ghironi (forthcoming, b) focus on how reforms in the Euro Area affect U.S.-Europe interdependence. We study the effects of implementing market reforms during recessions in Cacciatore, Duval, Fiori, and Ghironi (2015). Langot, Patureau, and Sopraseuth (2014) focus on the fiscal side of the structural reform debate - the reduction of tax-induced inefficiency wedges - in a model with labor, but not product, market dynamics.

${ }^{4}$ These findings are qualitatively in line with existing DSGE model-based and empirical literature, with the partial exception of employment protection reform, which has been found to have ambiguous effects on unemployment in other theoretical and empirical studies. In our model and calibration, employment protection reform (a reduction of firing costs and the bargaining power of individual workers) reduces unemployment.

${ }^{5}$ For tractability, we assume that agents engage in perfect risk sharing within their households. Thus, we do not
} 
The short-term effects of structural reform in one area depend in part on existing policy and institutional settings in other areas. For instance, short-term dynamics in the aftermath of product market reform are smoother if the labor market is more flexible. However, the long-term gains from product market reform are then smaller, i.e., there is long-run substitutability (rather than complementarity) between product and labor market reforms.

Policy can exploit the interdependence in the consequences of institutional settings across markets to minimize the transition costs of reforms. This is accomplished by implementing broad packages of labor and product market reforms. Specifically, reducing entry barriers in product markets in parallel to labor market reforms reverses the real wage losses and implied unfavorable demand effects that would result from the latter alone. ${ }^{6}$

Importantly, structural reforms are not found to have noticeable deflationary effects. This result contrasts with the implications of exogenous price and wage markup cuts in Eggertsson, Ferrero, and Raffo (2014) and other studies that use the same approach to modeling reforms. It suggests that inability of monetary policy to deliver interest rate cuts in the aftermath of reformseither because of the ZLB or because the country belongs to a monetary union-may not be an obstacle to reform implementation. ${ }^{7}$ Alternative simple, empirically relevant monetary policy rules do not imply large changes in transition costs. This is because the dynamic adjustment to reform is primarily driven by firm and consumer expectations of long-run effects of reforms that do not depend on monetary policy. The welfare costs of transition dynamics are only marginally smaller if the reforming country has a floating exchange rate than belonging to a monetary union.

Finally, the paper abstracts from the existence of political incentives and constraints in implementing market reform: We take deregulation as given and study its macroeconomic effects. Nevertheless, our results have implications for the political economy literature. On one side, the existence of short-run costs following individual reforms (e.g., barriers to entry and employment

address the distributional consequences of reforms. While this is an important topic for future research, we believe that the channels through which market reforms affect aggregate macroeconomic dynamics in the present study are likely to be robust to future analysis. For instance, in a search-and-matching model featuring Bewley-HuggettAiyagari incomplete markets, Krusell, Mukoyama, and Sahin (2010) show that raising unemployment benefits reduces long-run welfare, since aggregate labor-market inefficiencies significantly outweigh the benefits from insurance beyond self-insurance. In a similar model, Nakajima (2012) shows that the cyclical properties of unemployment and vacancies are little affected by strengthening or shutting down the uninsured individual unemployment risk.

${ }^{6}$ This result is consistent with the view that deregulating product markets first (or in conjunction to labor) can both mitigate the negative short-term impact of labor market reforms and facilitate their implementation-a point made by Blanchard and Giavazzi (2003), though in a static framework.

${ }^{7}$ Cacciatore, Fiori, and Ghironi (forthcoming, a and b) find that the optimal monetary policy response to market reform is expansionary, but this is driven by an incentive to front-load long-run gains rather than a response to sizable deflationary effects in the short run. 
protection legislation) offers an alternative explanation for the historical aversion of governments to implement market deregulation, adding to the traditional sources of status-quo bias highlighted by the political economy literature. ${ }^{8}$ On the other side, since joint deregulation in product and labor markets reduces short-run costs, a broad reform agenda may weaken the political opposition to reforms, helping to break the deadlock in highly regulated economies. This finding is consistent with the view in the political economy literature that reform packages are politically more viable than individual reforms (Saint-Paul, 2000).

The rest of the paper is organized as follows. Section 2 presents the model. Section 3 presents the calibration and results of our baseline exercise. Section 4 analyzes the consequences of reform packages. Section 5 focuses on the role of monetary policy. Section 6 concludes.

\section{The Model}

\section{Household Preferences}

We consider a small open economy populated by a unit mass of infinitely lived, atomistic households. Each household is thought of as a large extended family with a continuum of members on the unit interval. In equilibrium some members will be employed while others will be unemployed. Unemployed workers receive a fixed amount $w^{u}>0$ of household production units. As customary in the literature, family members perfectly insure each other against variation in labor income due to employment status, so that there is no ex-post heterogeneity across individuals (see Andolfatto, 1996, and Merz, 1995). We assume habit persistence in consumption utility as this improves the quantitative performance of the model by slowing down the response of consumption to shocks.

The representative household maximizes expected intertemporal utility, $E_{t}\left(\sum_{s=t}^{\infty} \beta^{s-t} u\left(C_{s}^{H}, C_{s-1}^{H}\right)\right)$, where the discount factor $\beta$ and habit parameter $h$ both lie between 0 and 1 , and the period utility function takes the form $u\left(C_{s}^{H}, C_{s-1}^{H}\right)=\left(C_{s}^{H}-h C_{s-1}^{H}\right)^{1-\gamma} /(1-\gamma)$, with $\gamma>0$. Household consumption $C_{t}^{H}$ is defined as

$$
C_{t}^{H} \equiv C_{t}+w^{u}\left(1-L_{t}\right)
$$

where $L_{t}$ is the number of employed workers, and $C_{t}$ is an Armington basket of domestic and

\footnotetext{
${ }^{8}$ These factors include, among others, the concentration of losses and diffusion of gains (Olson, 1965), the ex-ante uncertainty regarding the distribution of gains and losses (Fernandez and Rodrik, 1991), the conflict between insiders and outsiders (Blanchard and Giavazzi, 2003), and what Saint-Paul (2000) labels the constituency and identifiability effects. The former captures the notion that existing product and labor market institutions create their own political support, generating resistance to reform. The latter reflects the fact that gainers and losers from an institution currently in place are better identified than those from an institution not currently prevailing.
} 
imported consumption sub-bundles defined by:

$$
C_{t} \equiv\left[(1-\alpha)^{\frac{1}{\phi}} C_{d, t}^{\frac{\phi-1}{\phi}}+\alpha^{\frac{1}{\phi}}\left(C_{x, t}^{*}\right)^{\frac{\phi-1}{\phi}}\right]^{\frac{\phi}{\phi-1}}, \quad \alpha \in(0,1), \phi>0 .
$$

In this expression $(1-\alpha)$ capture the degree of home bias in preferences and $\phi$ is the elasticity of substitution across domestic and foreign output bundles. Note that $w^{u}$ is defined in the same units as $C_{t}$.

\section{Production}

Household members are employed by perfectly competitive firms to produce a non tradable intermediate input that is sold to monopolistically competitive wholesale producers. These use the intermediate input to produce differentiated consumption goods. Importantly, the number of producers in the wholesale sector is endogenous, and it varies in response to aggregate shocks. ${ }^{9}$ In the final stage of production, perfectly competitive retailers combine bundles of domestic differentiated goods and imported varieties to produce a final homogeneous good, $Y_{t}$.

\section{Retailers}

Firms in the retail sector are perfectly competitive and demand both domestic $\left(Y_{d, t}\right)$ and imported goods $\left(Y_{x, t}^{*}\right)$ to produce $Y_{t}$ :

$$
Y_{t}=\left[(1-\alpha)^{\frac{1}{\phi}} Y_{d, t}^{\frac{\phi-1}{\phi}}+\alpha^{\frac{1}{\phi}}\left(Y_{x, t}^{*}\right)^{\frac{\phi-1}{\phi}}\right]^{\frac{\phi}{\phi-1}} .
$$

The corresponding aggregate price index is given by

$$
P_{t}=\left[(1-\alpha) P_{d, t}^{1-\phi}+\alpha\left(P_{x, t}^{*}\right)^{1-\phi}\right]^{\frac{1}{\phi-1}}
$$

The sub-baskets $Y_{d, t}$ and $Y_{x, t}^{*}$ are aggregates of differentiated goods produced by Home and

\footnotetext{
${ }^{9}$ In Cacciatore, Duval, Fiori, and Ghironi (2015), we focus on producer entry dynamics and market deregulation in a non-traded sector that produces services used as an input in manufacturing production. There, we study the argument often made in policy discussions that reform of the domestic service sector can be beneficial for external competitiveness by lowering costs for tradable production. Our findings suggest that the alternative modeling structure does not affect the main results of this paper.
} 
Foreign wholesale producers:

$$
Y_{d, t}=\left(\int_{\omega \in \Omega} y_{d, t}(\omega)^{\frac{\theta-1}{\theta}} d \omega\right)^{\frac{\theta}{\theta-1}}, \quad Y_{x, t}^{*}=\left(\int_{\omega \in \Omega} y_{x, t}^{*}(\omega)^{\frac{\theta-1}{\theta}} d \omega\right)^{\frac{\theta}{\theta-1}},
$$

where $\theta>1$ is the elasticity of substitution between individual goods, and $\Omega$ is the set of all wholesale differentiated goods to which retailers (and, in turn, consumers) would like to have access to. In each period $t$, only subsets $\Omega_{t}$ and $\Omega_{t}^{*}$ of $\Omega$ are actually produced domestically and abroad, respectively. This implies price sub-indexes:

$$
\begin{aligned}
& P_{d, t}=\left(\int_{\omega \in \Omega_{t}} p_{d, t}(\omega)^{1-\theta} d \omega\right)^{\frac{1}{\theta-1}} \\
& P_{x, t}^{*}=\left(\int_{\omega \in \Omega_{t}} p_{x, t}^{*}(\omega)^{1-\theta} d \omega\right)^{\frac{1}{\theta-1}},
\end{aligned}
$$

where $p_{d, t}(\omega)$ is the price of a differentiated good produced and sold domestically and $p_{x, t}^{*}(\omega)$ is the price of an imported good, both expressed in units of home currency. ${ }^{10}$

\section{Incumbent Wholesalers}

Each incumbent wholesale firm serves both domestic and foreign retailers. Exporting is costly due to the presence of iceberg trade costs $\tau_{t}$ : Delivering one unit of good to the export market requires shipping $\tau_{t}>1$ units. Wholesale producer $\omega$ uses the intermediate input to produce with the linear technology $y_{t}(\omega)=y_{t}^{I}(\omega)$, where $y_{t}^{I}(\omega)$ is the amount of intermediate input used by producer $\omega$.

Domestic demand for home good $\omega$ is given by:

$$
y_{d, t}(\omega)=(1-\alpha)\left(\frac{p_{d, t}(\omega)}{P_{d, t}}\right)^{-\theta}\left(\frac{P_{d, t}}{P_{t}}\right)^{-\phi} Y_{d, t}
$$

We assume that the share of the small economy's goods consumed in the rest of the world is positive but negligible from the rest of the world's perspective. Export demand for the same domestic producer $\omega$ is:

$$
y_{x, t}(\omega)=\alpha\left(\frac{p_{x, t}(\omega)}{P_{x, t}}\right)^{-\theta}\left(\frac{P_{x, t}}{P_{t}^{*}}\right)^{-\phi} Y_{x, t}^{*},
$$

\footnotetext{
${ }^{10}$ Currency only serves as a unit of account in our model, and we work in a cashless environment as in Woodford (2003).
} 
where $p_{x, t}(\omega)$ is the price of the exported good in the foreign currency, and $P_{x, t}$ and $P_{t}^{*}$ are defined analogously to (1) and (2). Notice that (4) implies that the domestic producer faces a downward sloping demand for its own product in the international market. Hence, in the aggregate, the small open economy maintains the ability to affect its terms of trade.

Define the real prices $\rho_{d, t}(\omega) \equiv p_{d, t}(\omega) / P_{t}$ and $\rho_{x, t}(\omega) \equiv p_{x, t}(\omega) / P_{t}^{*}$. The expressions (3) and (4) can be rearranged as:

$$
y_{d, t}(\omega)=(1-\alpha)\left(\rho_{d, t}(\omega)\right)^{-\theta}\left(\frac{P_{d, t}}{P_{t}}\right)^{\theta-\phi} Y_{t}, \quad y_{x, t}(\omega)=(1-\alpha)\left(\rho_{x, t}(\omega)\right)^{-\theta}\left(\frac{P_{x, t}^{*}}{P_{t}^{*}}\right)^{\theta-\phi} Y_{t}^{*}
$$

We assume producer currency pricing. ${ }^{11}$ The law of one price (adjusted for the presence of iceberg trade costs) requires $p_{x, t}(\omega)=\tau_{t} \varepsilon_{t} p_{d, t}(\omega)$, where $\varepsilon_{t}$ is the nominal exchange rate. Following Rotemberg (1982), wholesale good prices are sticky in the form of a quadratic price adjustment $\operatorname{cost} \Gamma_{t}(\omega)$ defined as:

$$
\Gamma_{t}(\omega) \equiv \frac{\nu}{2} \pi_{t}^{2}(\omega)\left[\rho_{d, t}(\omega) y_{d, t}(\omega)+Q_{t} \rho_{x, t}(\omega) y_{x, t}(\omega)\right]
$$

where $\nu \geq 0$ (prices are flexible if $\nu=0$ ), $\pi_{t}(\omega) \equiv\left(p_{d, t}(\omega) / p_{d, t-1}(\omega)\right)-1$, and $Q_{t} \equiv \varepsilon_{t} P_{t}^{*} / P_{t}$ is the real exchange rate. ${ }^{12}$ Using the law of one price, we have:

$$
\Gamma_{t}(\omega)=\frac{\nu}{2} \pi_{t}^{2}(\omega) \rho_{d, t}^{1-\theta}(\omega) \Xi_{t}
$$

where

$$
\Xi_{t} \equiv(1-\alpha)\left(\frac{P_{d, t}}{P_{t}}\right)^{\theta-\phi} Y_{d, t}+\alpha \tau_{t}^{1-\theta} Q_{t}^{\theta}\left(\frac{P_{x, t}}{P_{t}^{*}}\right)^{\theta-\phi} Y_{x, t}^{*} .
$$

Total revenue for producer $\omega$ is given by:

$$
\rho_{d, t}(\omega) y_{d, t}(\omega)+Q_{t} \rho_{x, t}(\omega) y_{x, t}(\omega)=\rho_{d, t}^{1-\theta}(\omega) \Xi_{t}
$$

\footnotetext{
${ }^{11}$ In earlier versions of the paper, we explored the consequences of local currency pricing, finding that the currency denomination of exports does not significantly affect short-run dynamics following deregulation. Details are available on request.

${ }^{12}$ Notice that $\nu$ is denominated in units of consumption and the total price adjustment cost is proportional to the firm's total revenue. The latter assumption captures the idea that larger firms need to purchase larger amounts of materials when implementing price changes as standard in the literature that builds on Rotemberg's (1982) model of price rigidity.
} 
Total cost is given by:

$$
\varphi_{t}\left(y_{d, t}(\omega)+\tau_{t} y_{x, t}(\omega)\right)+\Gamma_{t}(\omega)=\varphi_{t} \rho_{d, t}^{-\theta}(\omega) \Xi_{t}+\frac{\nu}{2} \pi_{t}^{2}(\omega) \rho_{d, t}^{1-\theta}(\omega) \Xi_{t}
$$

where $\varphi_{t}$ is the price of the intermediate input (in unit of consumption). Hence, total profits (which will be distributed to households as dividends) are:

$$
d_{t}(\omega)=\left(\rho_{d, t}^{1-\theta}(\omega)-\varphi_{t} \rho_{d, t}^{-\theta}(\omega)-\frac{\nu}{2} \pi_{t}^{2}(\omega) \rho_{d, t}^{1-\theta}(\omega)\right) \Xi_{t}
$$

Firm $\omega$ maximizes the present discounted value of the stream of current and future profits $E_{t}\left[\sum_{s=t}^{\infty} \beta_{t, s}(1-\delta)^{s-t} d_{s}(\omega)\right]$, where $\beta_{t, s} \equiv \beta^{s-t} u_{C_{H, s}} / u_{C_{H, t}}$ is the stochastic discount factor, $u_{C_{H, t}}$ is the marginal utility of household consumption, and $(1-\delta)$ is the probability of firm survival until the next period (see below). ${ }^{13}$

Dropping the product identifier $\omega$ since home wholesalers are symmetric in equilibrium, the first-order condition with respect to $\rho_{d, t}$ yields the optimal pricing equation $\rho_{d, t}=\mu_{t} \varphi_{t}$, where $\mu_{t}$ is a time-varying markup given by:

$$
\mu_{t} \equiv \frac{\theta}{(\theta-1)\left(1-\frac{\nu}{2} \pi_{t}^{2}(\omega)\right)+\nu\left\{\left(\pi_{t}+1\right) \pi_{t}-(1-\delta) E_{t}\left[\beta_{t, t+1}\left(\pi_{t+1}+1\right) \pi_{t+1}\right]\right\} \frac{\rho_{d, t+1}}{\rho_{d, t}} \frac{y_{d, t+1}+y_{x, t+1}}{y_{d, t}+y_{x, t}}} .
$$

The markup reduces to the familiar constant $\mu=\theta /(\theta-1)$ if prices are flexible. ${ }^{14}$ The export price is determined by $\rho_{x, t}=\tau_{t} \mu_{t} \varphi_{t} / Q_{t}$. Prices of individual foreign wholesale goods are determined in a similar manner by $\rho_{d, t}^{*}=\mu_{t}^{*} \varphi_{t}^{*}$ and $\rho_{x, t}^{*}=\tau_{t} Q_{t} \mu_{t}^{*} \varphi_{t}^{*}$.

\section{The Number of Firms and Producer Entry}

Building on Bilbiie, Ghironi, and Melitz (2012), the number of firms operating in the wholesale sector at home and abroad is endogenous and varies in response to shocks. ${ }^{15}$ Denote with $N_{t}$ the

\footnotetext{
${ }^{13}$ We are implicitly assuming that all firms are fully owned domestically.

${ }^{14}$ Since the assumption of C.E.S. Dixit-Stiglitz aggregation of wholesale goods implies constant flexible-price markups, the model of this paper does not capture a pro-competitive effect of product market deregulation via through lower flexible-price markups. The models in Cacciatore and Fiori (forthcoming) and Cacciatore, Fiori, and Ghironi (forthcoming, a) capture such effect by assuming translog preferences (and, therefore, flexible-price markups that decrease if the number of producers in the economy increases).

${ }^{15}$ While we refer to the producers of individual wholesale goods as firms for convenience, it should be noted that we could also interpret them as product lines within multi-product firms whose boundaries we leave unspecified, as long as these firms are small relative to the overall size of the market. In this interpretation, entry refers to the within-firm product creation margin, which has been shown to be quantitatively important over the length of business cycles. See Bilbiie, Ghironi, and Melitz (2012) for discussion.
} 
mass of domestic wholesale producers on the market in period $t$ (the mass of the set $\Omega_{t}$ ). As implicit in the specification of costs above, there are no fixed costs of production. Therefore, all the firms that enter the economy (a mass $N_{E, t}$ in period $t$ ) produce in every post-entry period unless they are hit by an exogenous exit shock which occurs with probability $\delta \in(0,1)$ at the end of every period. ${ }^{16}$

Prior to entry, firms face a sunk entry cost $f_{E, t}$ in units of intermediate input. This is interpreted as a combination of technological requirements for business creation, $f_{T, t}$, and regulatory barriers to entry, $f_{r}$. Both components of entry costs are exogenous and potentially subject to shocks (for simplicity, there is no time index on $f_{r}$ because we will consider only permanent changes in this component). Prospective entrants are forward looking and anticipate their future profits $d_{s}(\omega)$ in any period $s>t$ as well as the exogenous probability $\delta$ of incurring the exit-inducing shock. As in Bilbiie et al. (2012), we assume that entrants at time $t$ will start producing only from $t+1 .{ }^{17}$ Prospective entrants compute their expected post-entry value $e_{t}(\omega)$, given by the presented discounted value of the expected stream of per-period profits $d_{s}(\omega)$ that they will generate from period $t+1$ on:

$$
e_{t}(\omega)=E_{t}\left[\sum_{s=t+1}^{\infty} \beta_{t, s}(1-\delta)^{s-t} d_{s}(\omega)\right] .
$$

Entry occurs until this firm value is equalized to the entry cost, leading to the free entry condition $e_{t}(\omega)=\varphi_{t} f_{E, t} .{ }^{18}$ Note that $e_{t}(\omega)=e_{t}$ is also the value of incumbent firms in period $t$. Given the time-to-build assumption, the law of motion for the number of wholesale producers is given by $N_{t}=(1-\delta)\left(N_{t-1}+N_{E, t-1}\right)$. The number of producing firms represents the stock of capital of the economy. It behaves much like physical capital in standard real business cycle models and has an endogenously fluctuating price given by (5).

\section{Intermediate Sector}

Perfectly-competitive firms in this sector produce a non-traded intermediate input using labor. The labor market is characterized by search-and-matching frictions as in Diamond (1982a,b) and

\footnotetext{
${ }^{16}$ We abstract from endogenous firm exit to simplify the model. Endogenous exit would require firm heterogeneity and fixed production costs. As noted by Bilbiie, Ghironi, and Melitz (2012), the simpler model is sufficient to capture important features of product market and aggregate dynamics with plausible calibrations of $\delta$.

${ }^{17}$ To simplify the model, we assume that the first price setting decision by new entrants in period $t$ (which will take place at $t+1$ ) is subject to the same rigidity as for incumbent firms. As shown in Bilbiie, Ghironi, and Melitz (2008), assuming that new entrants set their first price in flexible fashion does not alter the properties of the model significantly for realistic values of $\delta$.

${ }^{18}$ This condition holds with equality as long as the mass of new entrants $N_{E, t}$ is positive in all periods. We verify that this condition is never violated in our exercises.
} 
Mortensen and Pissarides (1994). Each firm employs a continuum of workers. The stock of labor varies because of endogenous variation in hiring (job creation) and firing (job destruction). To hire new workers firms must post vacancies, incurring a fixed cost $\kappa$ denominated in units of final output $Y_{t}$. The probability of finding a worker depends on a constant-returns-to-scale matching technology that converts aggregate unemployed workers $U_{t}$ and aggregate vacancies $V_{t}$ into aggregate matches $M_{t}$ :

$$
M_{t}=\chi U_{t}^{\varepsilon} V_{t}^{1-\varepsilon}, \quad 0<\varepsilon<1 .
$$

Labor market tightness is defined as $\vartheta_{t} \equiv V_{t} / U_{t}$. Each firm meets unemployed workers at a rate $q_{t}=M_{t} / V_{t}$. As in Krause and Lubik (2007), we assume that newly created matches become productive only in the next period. For an individual firm, the inflow of new hires in $t+1$ is therefore $q_{t} v_{t}$, where $v_{t}$ is the number of posted vacancies.

Firms and workers can separate for exogenous and endogenous reasons. When the firm finds a match to be no longer profitable, it can dismiss the worker but, to do so, it has to incur a firing cost $F$ denominated in units of final output $Y_{t}$. This cost is constant and proportional to the steady-state (aggregate) real wage $\bar{w}: F=\psi_{F} \bar{w}$, where $\psi_{F}$ is a positive parameter, and we denote steady-state levels of variables by dropping the time index. ${ }^{19}$

Production is subject to both aggregate and idiosyncratic shocks. Specifically, each filled job produces $Z_{t} z_{j t}$ units of output, where $j$ indexes a particular job. Aggregate productivity $Z_{t}$ is common to all firms and follows an $A R(1)$ process in logs, while the specific job's productivity $z_{j t}$ is idiosyncratic. Job-specific productivity is an i.i.d. draw from a time invariant distribution with cumulative distribution function $G(z)$, positive support, and density $g(z) .{ }^{20}$

For a generic intermediate input producer, total output $y_{t}^{I}$ is determined by the measure $l_{t}$ of jobs, aggregate productivity $Z_{t}$, and the average of idiosyncratic job-specific shocks, $\bar{z}_{t}$ :

$$
y_{t}^{I}=Z_{t} l_{t} \int_{z_{t}^{F}}^{\infty} \frac{z}{1-G\left(z^{F}\right)} d G(z) \equiv Z_{t} \bar{z}_{t} l_{t}
$$

where $z_{t}^{F}$ is the (endogenous) critical threshold below which firms destroy non profitable jobs with

\footnotetext{
${ }^{19}$ Firing costs are not a transfer to workers here and are treated as a pure loss (administrative costs of layoff procedures). Severance transfers from firms to workers would have no allocative effects with Nash wage bargaining as assumed below. See Mortensen and Pissarides (2002).

${ }^{20}$ As common in the literature, the i.i.d. assumption is for analytical tractability. A more realistic assumption would be to allow idiosyncratic shocks to display persistence. Results in den Haan, Ramey, and Watson (2000) lead us to conjecture that this would not affect our results significantly.
} 
productivity $z_{j t}<z_{t}^{F} \cdot{ }^{21}$

Denote with $\lambda^{S}$ the fraction of jobs that are exogenously separated at the beginning of each period. Total separation is then given by $\lambda_{t} \equiv \lambda^{S}+\lambda_{t}^{F}$, where $\lambda_{t}^{F} \equiv\left(1-\lambda^{S}\right) G\left(z_{t}^{F}\right)$ is the fraction of jobs that are endogenously destroyed. It follows that the law of motion of employment at the representative intermediate sector firm is given by:

$$
l_{t}=\left(1-\lambda_{t}\right)\left(l_{t-1}+q_{t-1} v_{t-1}\right) .
$$

Intermediate input producers choose vacancies $\left(v_{t}\right)$, employment $\left(l_{t}\right)$, and the threshold productivity for firing $\left(z_{t}^{F}\right)$ to maximize the expected present discounted value of current and future profits

$$
E_{t}\left\{\sum_{s=t}^{\infty} \beta_{t, s}\left[\varphi_{s} Z_{s} \bar{z}_{s} l_{s}-\bar{w}_{s} l_{s}-\kappa v_{s}-\lambda_{s}^{F}\left(1-\lambda^{S}\right)\left(l_{s-1}+q_{s-1} v_{s-1}\right) F\right]\right\}
$$

subject to (7). The first term in the period profit function is the real value of the intermediate producer's output, with $\varphi_{t} \equiv p_{t}^{I} / P_{t}$ its real price. The real wage $\bar{w}_{t}$ is an aggregate of individual wages determined as described below. The last two terms reflect hiring and firing costs.

First-order conditions with respect to $v_{t}, l_{t}$, and $z_{t}^{F}$ are, respectively:

$$
\begin{gathered}
\frac{\kappa}{q_{t}}=\left(1-\lambda^{S}\right) E_{t}\left\{\beta_{t, t+1}\left[\phi_{t+1}\left(1-\lambda_{t+1}^{F}\right)-\lambda_{t+1}^{F} F\right]\right\} \\
\phi_{t}=\varphi_{t} Z_{t} \bar{z}_{t}-\bar{w}_{t}+\left(1-\lambda^{S}\right) E_{t}\left\{\beta_{t, t+1}\left[\phi_{t+1}\left(1-\lambda_{t+1}^{F}\right)-\lambda_{t+1}^{F} F\right]\right\}, \\
\varphi_{t} Z_{t} z_{t}^{F}=w_{t}^{F}-F-\frac{\kappa}{q_{t}}
\end{gathered}
$$

where $\phi_{t}$ is the Lagrange multipliers attached to (7) and represents the current period (average) value of an extra worker for the producer, and $w_{t}^{F}$ is the real wage of the marginal worker. Equation (8) states that at an optimum, the cost of posting a successfully filled vacancy must be equal to its expected discounted value to the firm, net of the firing cost that may be incurred next period. Equation (9) states that the value of an extra worker must equate its (average) net cost plus the expected continuation value of the match. Equation (10) states that the marginal revenue product of the threshold worker must be equal to its wage cost net of the costs the firm has to bear to fire the worker and post the vacancy to seek a replacement.

\footnotetext{
${ }^{21}$ In Cacciatore, Duval, Fiori, and Ghironi (2015), we extend the model to include endogenous physical capital accumulation. The presence of physical capital enhances the persistence of macroeconomic dynamics in response to deregulation, yet leaves unaffected the qualitative pattern of transition dynamics.
} 


\section{Wage Determination}

The wage schedule is obtained through the solution of an individual Nash bargaining problem. Without loss of generality, we consider a worker with idiosyncratic productivity $z$. The bargaining solution splits the surplus of the match between the worker and the firm in shares determined by an exogenous bargaining weight $\eta$ between 0 and 1 according to the sharing rule:

$$
\eta J_{t}(z)=(1-\eta)\left(W_{t}(z)-U_{u, t}\right)
$$

where $J_{t}(z)$ is the firm's surplus from employing worker $z, W_{t}(z)$ represents the worker's asset value of being employed, and $U_{u, t}$ is the value of unemployment. ${ }^{22}$ As pointed out by Mortensen and Pissarides (2002), the firm surplus corresponds to the value of the job to the firm, $\phi_{t}(z)$, plus savings from firing costs: $J_{t}(z)=\phi_{t}(z)+F{ }^{23}$ The value of the job to the firm is determined by the marginal revenue product of the employment relation minus its costs, plus its expected discounted continuation value:

$$
\phi_{t}(z)=\varphi_{t} Z_{t} z-w(z)+\left(1-\lambda^{S}\right) E_{t}\left\{\beta_{t, t+1}\left[\left(1-\lambda_{t+1}^{F}\right) \phi_{t+1}-\lambda_{t+1}^{F} F\right]\right\}
$$

where $\phi_{t}$ is defined by equation (9). Using equation (8), the firm surplus can be written as

$$
J_{t}(z)=\varphi_{t} Z_{t} z-w(z)+\frac{\kappa}{q_{t}}+F
$$

The worker's surplus is:

$$
W_{t}(z)-U_{u, t}=\left(1-\tau^{w}\right) w_{t}(z)-b+\left(1-\iota_{t}\right) E_{t}\left[\beta_{t, t+1}\left(1-\lambda_{t+1}\right)\left(\bar{W}_{t+1}-U_{u, t+1}\right)\right]
$$

where $\tau^{w}$ is the labor income tax rate, $\iota_{t} \equiv M_{t} / U_{t}$ is the endogenous probability of finding a job in period $t$, and

$$
\bar{W}_{t+1}=\int_{z_{t+1}^{F}}^{\infty} \frac{W_{t+1}(z)}{1-G\left(z_{t}^{F}\right)} d G(z) .
$$

The worker's outside option (identical across workers) is given by $b \equiv w^{u}+\psi_{b} \bar{w}$, where $\psi_{b}$ is a

\footnotetext{
${ }^{22}$ This bargaining weight $\eta$ captures the bargaining power of individual workers. We will introduce real wage rigidity below by assuming gradual adjustment of real wages from their initial (pre-reform) levels to their Nash-bargaining levels (which will differ from the initial steady-state levels insofar as reforms change the Nash-bargaining weight $\eta$ ).

${ }^{23}$ The outside option for the firm in wage negotiations is firing the worker, paying $F$.
} 
positive parameter. The first term is home production, while the second is a transfer from the government interpreted as unemployment benefits. Worker surplus equals the wage net of the outside option plus expected discounted future surplus, accounting for endogenous variation in the future firing threshold.

Notice that the sharing rule implies $(1-\eta)\left(\bar{W}_{t+1}-U_{u, t}\right)=\eta \bar{J}_{t+1}$, where

$$
\bar{J}_{t+1} \equiv \int_{z_{t+1}^{F}}^{\infty} \frac{J_{t+1}(z)}{1-G\left(z_{t}^{F}\right)} d G(z)=\phi_{t+1}+F
$$

Therefore, equation (13) can then be written as

$$
W_{t}(z)-U_{u, t}=\left(1-\tau^{w}\right) w_{t}(z)-b+\frac{\eta}{1-\eta}\left(1-\iota_{t}\right) E_{t}\left[\beta_{t, t+1}\left(1-\lambda_{t+1}\right)\left(\phi_{t+1}+F\right)\right]
$$

or, using equation (8):

$$
W_{t}(z)-U_{u, t}=\left(1-\tau^{w}\right) w_{t}(z)-b+\frac{\eta}{1-\eta}\left(1-\iota_{t}\right)\left[\frac{\kappa}{q_{t}}+\left(1-\lambda^{S}\right) E_{t} \beta_{t, t+1} F\right]
$$

Substituting (12) and (14) into the bargaining rule (11) yields the equation for the individual real wage:

$$
w_{t}(z)=\frac{\eta\left\{\varphi_{t} Z_{t} z+\kappa \vartheta_{t}+\left[1-\left(1-\lambda^{S}\right)\left(1-\iota_{t}\right) E_{t} \beta_{t, t+1}\right] F\right\}+(1-\eta) b}{\eta+(1-\eta)\left(1-\tau^{w}\right)} .
$$

The bargained wage is a weighted average between the marginal revenue product of the match (plus a firing costs component) and the worker's outside option. The wage is intuitively increasing in the marginal revenue product of labor, the tightness of the labor market, and the worker's outside option. Firing costs affect $w_{t}(z)$ in the following way: The firm rewards the worker for the saving in firing costs today (the first term in the square bracket in equation (15)), but it penalizes the worker for the fact that, in the case of firing, it will have to pay firing costs tomorrow.

As shown in Hall (2005) and Shimer (2005), real wage rigidity improves the performance of the search-and-matching model in terms of the dynamics of labor market variables. We introduce a simple form of real wage rigidity that well serves the purposes of this paper by borrowing from Hall (2005). In particular, we assume that the individual real wage actually paid to worker $z$ is a weighted average of the one obtained through the Nash bargaining process in period $t$ and its constant steady-state level: $w_{a, t}(z) \equiv \varrho w_{t}(z)+(1-\varrho) w(z)$, with $\varrho$ between 0 and $1 .{ }^{24}$ The aggregate

\footnotetext{
${ }^{24}$ For analyses of structural reforms in models of the type used here, but with sticky nominal wages, see Cacciatore,
} 
real wage $\bar{w}_{t}$ is the average of actual individual wages, weighted according to the distribution of idiosyncratic worker productivity:

$$
\bar{w}_{t} \equiv \int_{z_{t}^{F}}^{\infty} \frac{w_{a, t}(z)}{1-G\left(z^{c}\right)} d G(z)=\varrho \bar{w}_{a, t}+(1-\varrho) \bar{w}_{a} .
$$

The labor market structure of the economy can be summarized by a job creation equation, a job destruction equation, and the expression for the aggregate wage provided by (16). Combining (8) and (9) yields the job creation equation:

$$
\frac{\kappa}{q_{t}}=E_{t}\left\{\beta_{t, t+1}\left(1-\lambda_{t+1}\right)\left[\varphi_{t+1} Z_{t+1} \bar{z}_{t+1}-\bar{w}_{t+1}+\frac{\kappa}{q_{t+1}}\right]\right\}
$$

stating that the expected cost of posting a vacancy today, $\kappa / q_{t}$, has to be equal to its expected marginal benefit (determined by the probability of match survival, its marginal revenue product net of wage cost, and vacancy cost saving next period). The job destruction condition (10) determines the cutoff productivity for firing, $z_{t}^{F}$, a sufficient statistic for the behavior of job destruction. At the margin, the producer has to be indifferent between maintaining the match and firing the threshold worker.

\section{Household Budget Constraint and Intertemporal Decisions}

International financial markets are assumed to be incomplete. The representative household in the small open economy can invest in three types of assets: domestic and foreign bonds, and shares in a mutual fund of wholesale firms. ${ }^{25}$ Let $x_{t}$ be the share in the mutual fund of wholesale firms held by the representative household entering period $t$. The representative household buys $x_{t+1}$ shares in a mutual fund of all the firms existing at time $t$-incumbents and new entrants, $N_{t}+N_{E, t}$ - even though only a fraction $(1-\delta)$ of these firms will be producing in $t+1$. The household does not know which firms will be hit by the exit shock at the end of the period. Therefore, it finances continued operation of all incumbents, and the entry of new firms, and factors the exit risk in the pricing of the equity as determined below. The real price of one share at time $t$ is equal to the price of claims to future real profits $e_{t}$. Let $B_{t+1}$ denote nominal holdings of Home bonds (in home currency) and $B_{*, t+1}$ nominal holdings of foreign bonds (in foreign currency) entering period $t+1$.

Fiori, and Ghironi (forthcoming, a and b).

${ }^{25}$ New entrants finance entry costs by issuing equity on the stock market in this model. See Cacciatore, Ghironi, and Stebunovs (2015) for a version of the entry model based on bank finance. 
As in Turnovsky (1985) and, more recently, Benigno (2009), we assume quadratic costs of adjusting international bond holdings to pin down their steady-state level and ensure stationary responses to temporary shocks. These adjustment costs are paid to intermediaries whose only function is to collect them and rebate them to the household in lump-sum fashion. (Home currency bonds are held only domestically, so no adjustment cost is needed to pin down their steady-state level.) The period budget constraint of the household can be written as:

$$
\begin{gathered}
B_{t+1}+\varepsilon_{t} B_{*, t+1}+\frac{\xi}{2}\left(\frac{B_{*, t+1}}{P_{t}^{*}}\right)^{2} \varepsilon_{t}+P_{t} C_{t}+N_{E, t} e_{t} x_{t+1} \\
=\left(1+i_{t}\right) B_{t}+\varepsilon_{t}\left(1+i_{t}^{*}\right) B_{*, t}+P_{t}\left(d_{t}+e_{t}\right) N_{t} x_{t}+\left(1-\tau^{w}\right) P_{t} \bar{w}_{t} L_{t}+P_{t} b\left(1-L_{t}\right)+P_{t} T_{t}^{f}+P_{t} T_{t}+P_{t} T_{t}^{I},
\end{gathered}
$$

where $\xi>0, i_{t}\left(i_{t}^{*}\right)$ is the home (foreign) nominal interest rate between $t-1$ and $t$, determined by the home (foreign) central bank at $t-1 ; T_{t}^{f}$ is a lump-sum rebate of the international bond adjustment cost; $T_{t}$ is the lump-sum rebate of profits from intermediate goods producers.

Let $b_{*, t+1} \equiv B_{*, t+1} / P_{t}^{*}$ denote real holdings of foreign bonds. The Euler equations for domestic and foreign bonds are, respectively:

$$
\begin{gathered}
1=\left(1+i_{t+1}\right) E_{t}\left(\beta_{t, t+1} \frac{1}{1+\pi_{t+1}^{C P I}}\right), \\
1+\xi b_{*, t+1}=\left(1+i_{t+1}^{*}\right) E_{t}\left(\beta_{t, t+1} \frac{Q_{t+1}}{Q_{t}} \frac{1}{1+\pi_{t+1}^{* C P I}}\right),
\end{gathered}
$$

where $\pi_{t}^{C P I} \equiv\left(P_{t} / P_{t-1}\right)-1$ and the foreign CPI inflation rate is defined similarly, and the the Euler equations for share holdings is:

$$
e_{t}=(1-\delta) E_{t}\left[\beta_{t, t+1}\left(d_{t+1}+e_{t+1}\right)\right]
$$

Note that forward iteration of this equation in the absence of speculative bubbles yields the expression for firm value in the producer entry condition, providing the general equilibrium link between household and firm behavior with respect to saving and investment decisions. 


\section{Symmetric Equilibrium}

In equilibrium, the aggregate price index can be written as:

$$
1=(1-\alpha)\left(\frac{P_{d, t}}{P_{t}}\right)^{1-\phi}+\alpha\left(\frac{P_{x, t}^{*}}{P_{t}}\right)^{1-\phi},
$$

where:

$$
\frac{P_{d, t}}{P_{t}}=\rho_{d, t} N_{t}^{\frac{1}{1-\theta}}, \quad \frac{P_{x, t}}{P_{t}^{*}}=\rho_{x, t} N_{t}^{\frac{1}{1-\theta}}
$$

Combining equations (18) and (19) yields:

$$
1=\rho_{d, t}^{1-\phi}\left[(1-\alpha) N_{t}^{\frac{1-\phi}{1-\theta}}+\alpha\left(\tau_{t} Q_{t}\right)^{1-\phi} N_{t}^{* \frac{1-\phi}{1-\theta}}\right]
$$

Labor market equilibrium requires $L_{t}=l_{t}$ and $V_{t}=v_{t}$. Hence, the law of motion of aggregate employment can be written as:

$$
L_{t}=\left(1-\lambda_{t}\right)\left(L_{t-1}+q_{t-1} V_{t-1}\right) \text {. }
$$

Real profits from intermediate goods producers are given by

$$
T_{t}^{I}=\varphi_{t} Z_{t} \bar{z}_{t} l_{t}-\bar{w}_{t} L_{t}-\kappa V_{t}-\lambda_{t}^{F}\left(1-\lambda^{S}\right)\left(L_{t-1}+q_{t-1} V_{t-1}\right) F .
$$

The government collects taxes on labor income and pays unemployment benefits. In equilibrium, any difference between government revenue and expenses is financed by lump sum taxes $T_{t}$ :

$$
T_{t}=\tau^{w} \bar{w}_{t} L_{t}-\psi_{b} \bar{w}\left(1-L_{t}\right) .
$$

The lump-sum rebate of international bond adjustment costs is such that:

$$
T_{t}^{f}=\frac{\xi}{2}\left(\frac{B_{*, t+1}}{P_{t}^{*}}\right)^{2} \frac{\varepsilon_{t}}{P_{t}}
$$

Equilibrium in the markets for equity and the domestic bond requires $x_{t+1}=x_{t}=1$ and $B_{t+1}=B_{t}=0$. Because of linearity of technology, intermediate market clearing requires:

$$
Z_{t} \bar{z}_{t} L_{t}=N_{t}\left(y_{d, t}+\tau y_{x, t}\right)+N_{E, t} f_{E, t} .
$$


Finally, equilibrium of international payments implies

$$
Q_{t}\left(b_{*, t+1}-b_{*, t}\right)=Q_{t} r_{t}^{*} b_{*, t}+Q_{t} N_{t} \rho_{x, t} y_{x, t}-N_{t}^{*} \rho_{x, t}^{*} y_{x, t}^{*},
$$

where $r_{t}^{*}$ is the foreign real interest rate, defined by $1+r_{t}^{*}=\left(1+i_{t}^{*}\right) /\left(1+\pi_{t}^{* C P I}\right)$. The left-hand side of this equation is home's current account (or the change in home's net foreign asset position). This must be equal to the income balance (interest income on net foreign assets entering the period) plus the trade balance.

We define the terms of trade as the price of imports relative to exports: $T O T_{t} \equiv Q_{t} \rho_{x, t}^{*} / \rho_{x, t}$. We use the NIPA definition of GDP as total income:

$$
G D P_{t}=\bar{w}_{t} L_{t}+N_{t} d_{t}+T_{t}^{I}
$$

To close the model, we need to specify processes for $r_{t}^{*}, N_{t}^{*}, \rho_{x, t}^{*}$, and $y_{x, t}^{*}$, as well as the conduct of monetary policy for the small open economy. Since we focus only on domestic shocks, and the small open economy has a negligible impact on the rest of the world, we simply assume that foreign variables are constant and normalized to initial steady-state levels as standard practice in the literature.

\section{Welfare-Consistent versus Data-Consistent Variables}

A well established property of preferences or production functions that exhibit "love for variety" is that aggregate output and prices increase if the number of available products expands even if individual good quantities and prices do not change. For instance, under our assumptions,

$$
P_{t}^{1-\phi}=(1-\alpha) p_{d, t}^{1-\phi} N_{t}^{\frac{1-\phi}{1-\theta}}+\alpha p_{x}^{* 1-\phi} N^{* \frac{1-\phi}{1-\theta}}
$$

As the home economy experiences entry, the welfare-consistent aggregate price level $P_{t}$ fluctuates, even if individual product prices remain constant. As noted in Bilbiie, Ghironi, and Melitz (2012) and Ghironi and Melitz (2005), consumer price data do not correctly account for this variety effectnot only because adjustments for variety do not happen at the frequency required for consistency with the model, but also because adjustments are not designed to match the preference specification 
adopted in it. ${ }^{26}$ As a result, central banks decide monetary policy by using price index (and quantity) data that do not account for variety in model-consistent manner.

To obtain model-based price and quantity variables that are close to available data, we follow Feenstra (1994) and Ghironi and Melitz (2005) and observe that a data-consistent price index can be constructed as $\widetilde{P}_{t}=\Psi_{t}^{\frac{1}{\phi-1}} P_{t}$, where $\Psi_{t} \equiv(1-\alpha) N_{t}^{\frac{1-\phi}{1-\theta}}+\alpha N^{* \frac{1-\phi}{1-\theta}}$. The correction $\Psi_{t}$ removes the pure variety effect from the price index $P_{t}$, leaving us with an index of average prices that is consistent with CPI data. Data-consistent CPI inflation is then defined as $\tilde{\pi}_{t}^{C P I} \equiv\left(\widetilde{P}_{t} / \widetilde{P}_{t-1}\right)-1$. Finally, given quantity $X_{t}$ in units of consumption (therefore, including the variety effect), its data-consistent counterpart can be defined as $X_{R, t} \equiv P_{t} X_{t} / \widetilde{P}_{t}$.

\section{Monetary Policy}

The model is then closed by specifying the conduct of home's monetary policy. Under the benchmark scenario, we assume a floating nominal exchange rate regime and an interest rate reaction function according to which the central banks responds to movements in data-consistent CPI inflation and a data-consistent GDP gap relative to potential (defined as GDP in the equilibrium with flexible prices and wages):

$$
1+i_{t+1}=\left(1+i_{t}\right)^{\varrho_{i}}\left[(1+i)\left(1+\tilde{\pi}_{t}^{C P I}\right)^{\varrho_{\pi}}\left(G D P_{R, t}^{g a p}\right)^{\varrho_{Y}}\right]^{1-\varrho_{i}}
$$

As alternative scenario, we consider a currency union between the small open economy and the rest of the world. The union-wide monetary authority sets the nominal interest rate $i_{t+1}^{*}$ without responding to inflation and output dynamics of the small open economy, since the latter has a negligible impact on union-wide price indexes and macroeconomic aggregates.

\section{The Effects of Product and Labor Market Reforms}

In this section, we use a calibrated version of the model to study the consequences of alternative reforms of product and labor markets.

\footnotetext{
${ }^{26}$ Broda and Weinstein (2010) document that gains from variety go mostly unmeasured in CPI data. See also Feenstra (1994).
} 


\section{Calibration}

We interpret periods as quarters and set several parameters at standard values in the literature. Specifically, we set the discount factor $\beta$ at 0.99 , implying an annual real interest rate of 4 percent. The risk aversion coefficient $\gamma$ is equal to 2. The elasticity of substitution across domestic wholesale goods, $\theta$, is set to 11 to imply a relatively low degree of monopoly power of the small economy's wholesale producers. The elasticity of substitution between home and foreign bundles of products, $\phi$, is equal to 1.5 . The degree of home bias, $(1-\alpha)$, is set to 0.8 . The quadratic cost of adjusting prices $\nu$ is set to 80 as in Bilbiie, Ghironi, and Melitz (2008). This is a standard value for models that build on Rotemberg (1982). The parameter governing habit persistence, $h$, is set to 0.6 , and the scale parameter for the adjustment cost on foreign bonds is set to 0.004 .

We base the calibration of product and labor market regulation and other characteristics of these markets mostly on Euro Area evidence before the recent crisis. Product market regulation is calibrated based on evidence in Pissarides (2003), who compiles an index for producer entry delay as the number of business days that it takes (on average) to fulfill entry requirements, weighted by the number of procedures that must be performed. Following the procedure proposed by Ebell and Haefke (2009), we convert the average of this index for Euro Area countries into months of lost output. We then set the regulatory component, $f_{r}$, of firm entry costs so that the costs required to fulfill entry requirements amount to 0.81 quarters of lost output (based on 230 business days in a year). To pin down exogenous exit of firms, $\delta$, we target the portion of job destruction due to exit. Empirical evidence suggests that job destruction induced by plant exit ranges between 25 and 55 per cent in OECD countries. We choose a midpoint of those estimates and set $\delta$ that firm exit accounts for 40 percent of overall job destruction. ${ }^{27}$

Turning to the labor market, we set the elasticity of the matching function $\varepsilon$ to 0.6 , a midpoint of estimates reported in Petrongolo and Pissarides (2003). The parameter that determines the bargaining power of workers versus firms, $\eta$, is set to 0.6 to ensure that the Hosios condition $\varepsilon=\eta$ is satisfied in the initial steady state, and the parameter that governs real wage rigidity, $\varrho$, is set to 0.7 as in Campolmi and Faia (2011). Exogenous separation $\lambda^{S}$ is set equal to 0.68, as in den Haan, Ramey, and Watson (2000). The replacement rate $\psi_{b}$ is taken from OECD (2004) and set to 0.69. Given $F=\psi_{F} \bar{w}$, we follow Thomas and Zanetti (2009) and set $\psi_{F}=0.2$. The idiosyncratic job productivity shock $z$ is assumed lognormally distributed with mean 0 and standard deviation

\footnotetext{
${ }^{27}$ Note that we identify firms and plants in our model. Recall that firms in the model can be reinterpreted as product lines, making it more plausible for us to appeal to plant evidence for calibration.
} 
0.4, consistent with Thomas and Zanetti (2009). Since we focus only on the implications of the model for market reforms, we assume that exogenous aggregate productivity $Z_{t}$ is constant and normalized to 1 in all periods. ${ }^{28}$

Three labor market parameters are left to calibrate: the cost of vacancy posting, $\kappa$, the flow value of home production $h$, and the efficiency of the matching function, $\chi$. As common practice in the literature, we chose the values of these parameters to match the steady-state unemployment rate, $U$, probability of filling a vacancy, $q$, and total separation rate, $\lambda$. Total average separation, $\lambda$, is 5 percent in Hobjin and Sahin's (2007) empirical evidence, and ECB (2002) and Weber (2000) estimate values of $U$ and $q$ at 9 percent and 0.7 , respectively.

Finally, we need to calibrate the parameters of the monetary policy rule under flexible exchange rates. We compare the adjustment to reform under three different scenarios that illustrate the consequences of different approaches to policy In the benchmark case, $\varrho_{i}=0.8, \varrho_{\pi}=2$, and $\varrho_{Y}=0.2$. These parameter values fall within the standard ranges estimated from the behavior of many central banks since the 1990s. In the first alternative scenario, we increase the response of policy to inflation to $\varrho_{\pi}=9$ to capture the consequences of a stronger concern for price stability. In the second alternative scenario, we keep $\varrho_{\pi}$ at the benchmark level and increase the response of policy to the GDP gap to $\varrho_{Y}=0.8$ to capture the effects of stronger concern for output dynamics. The model calibration is summarized in Table 1.

\section{Structural Reforms and Their Calibration}

We explore the effects of structural reforms by studying the dynamic adjustment to the new long-run equilibrium following one-time, permanent change in product and labor market policy parameters. We consider four types of market reforms, treating them as unanticipated: (i) a relaxation of employment protection, modeled as a simultaneous reduction in firing costs and the bargaining power of individual workers ${ }^{29}$; (ii) a cut in the unemployment benefit replacement rate; (iii) a strengthening of activation labor market policies (ALMPs), modeled in a stylized way as a simultaneous increase in the efficiency of the job matching process and a reduction in the utility of being unem-

\footnotetext{
${ }^{28}$ Cacciatore, Fiori, and Ghironi (forthcoming, a and b) show that the type of model used in this paper successfully reproduces a number of features of business cycle data. See Cacciatore, Ghironi, and Turnovsky (2014) for the business cycle properties of a small open economy version of the framework calibrated to New Zealand.

${ }^{29}$ In the data, employment protection refers to all types of employment protection measures, whether grounded primarily in legislation, court rulings, collectively bargained conditions of employment, or customary practice. Blanchard and Giavazzi (2003) focus on a reduction in worker bargaining power in their model.
} 
ployed $^{30}$; (iv) a reduction in barriers to firm entry. The size of the changes in unemployment benefit, employment protection, and product market reform is pinned down by assuming that all relevant policy parameters are lowered from average levels prevailing across Euro Area countries (the values in the benchmark calibration above) to average levels prevailing across a group of (non-Euro Area) OECD countries where such parameters are estimated to characterize more flexible market conditions. Specifically, we assume that firing costs and worker bargaining power are reduced by 25 percent, and the replacement rate is lowered to $\psi_{b}=0.58$. Product market deregulation is a permanent decrease of regulatory barriers, $f_{r}$, to 0.40 quarters of lost output. ${ }^{31}$ For the ALMP reform, we consider a more arbitrary 25 percent change in the level of the parameters $\chi$ and $w^{u}$, which are, respectively, increased and reduced. ${ }^{32}$ Given the large size of the reform shocks, we solve the model using a Newton-type algorithm, first proposed by Laffargue (1990). The details of the algorithm can be found in Juilliard (1996).

We use the model to assess whether the dynamic effect of a given reform changes depending on policy settings in other areas. Specifically, we simulate the dynamic impact of reforms to employment protection and unemployment benefits under different levels of barriers to entry, and vice versa. All dynamic simulation results are presented in Figures 1 to 6, while the steady-state effects are shown in Table 2. We carried out sensitivity analysis which showed that results remain qualitatively unchanged under alternative values of key model parameters including the elasticity of substitution across domestic wholesale goods, the elasticity of substitution between domestic and foreign goods, bargaining power, or the variance of idiosyncratic productivity shocks. ${ }^{33}$

\footnotetext{
${ }^{30}$ This modeling choice can be justified on the grounds that stronger activation policies can deliver positive labour market outcomes through at least two channels: improving the efficiency of matching between workers and jobs, and increasing the motivation and ability of the unemployed to look effectively for a job. Regarding the latter channel, so-called "threat effects" from institutional mechanisms such as compulsory participation in active labor market programs or referral to ALMPs under threat of benefit sanctions have been identified in the literature (see Black et al., 2003, Geerdsen and Holm, 2007, and Kluve, 2010). Such activation mechanisms are not unusual in OECD countries, for instance, Denmark and Sweden, but also Australia and the United Kingdom. The basic idea is that unemployed individuals may find that compulsory participation lowers their well-being, e.g., if participation in the programme entails scarring effects or is seen as a tax on leisure.

${ }^{31}$ Due to data limitations and diversity of sources, the composition of the country group used to determine the size of each reform is slightly different across policy parameters. In particular, the target for flexible product market regulation is constructed as an average of Australia, Japan, Denmark, Sweden, the United Kingdom, and the United States. The target for unemployment benefits and employment protection includes Australia, Canada, Japan, Korea, New Zealand, Turkey, the United Kingdom, and the United States. To pin down the change in firing costs and worker bargaining power that capture a reform of employment protection, we consider the ratio of OECD indexes of employment protection (excluding the component relative to temporary workers) for this group of countries and the Euro Area in 2008. In the data, this ratio is equal to 0.75 .

${ }^{32}$ While arbitrary, the assumed 25 percent change in these parameters does not drive the main results from the ALMP reform simulations, as these results are qualitatively robust to alternative choices for the size of the reform.

${ }^{33}$ Results are available upon request.
} 


\section{The Dynamic Adjustment to Deregulation}

\section{Labor Market Reforms}

Employment Protection Reform Figure 1 presents selected impulse responses to a weakening of employment protection under the alternative calibrations of the monetary policy rule mentioned above. $^{34}$ This reform reduces real wages by lowering individual workers' bargaining power, and it reduces the expected cost for firms of terminating a job match (Figure 1). This boosts job creation. In the short run, however, the reduction in firing costs also reduces the profitability of less-productive job matches, inducing firms to layoff less productive workers. While the destruction of existing jobs is immediate, job creation is only gradual because it takes time to match firms and unemployed workers - both newly unemployed ones and incumbent members of the unemployment pool. Therefore, the unemployment rate increases in the aftermath of the reform, before declining gradually as new jobs are created.

The initial decline in employment and real wages reduces aggregate demand, ceteris paribus. However, households also anticipate a future increase in income, which leads them to reduce current saving. As a result of these two offsetting forces, consumption remains roughly unchanged, before increasing gradually as employment and income rise. GDP falls before rising above its pre-reform level already after a couple of quarters.

The relative price of home goods (i.e., the terms of trade) falls slightly due to a small decline in marginal costs, which in turn reflects lower wages and firing costs. ${ }^{35}$ This terms-of-trade depreciation generates a negative wealth effect due to the smaller revenue per exported good, but also expenditure switching toward home goods as these become cheaper than foreign ones, and a small improvement in the current account.

Despite the small decline in marginal costs associated with lower wages, there is a small initial pick-up in CPI inflation in equilibrium, reflecting mainly higher prices of imported goods. Over time, the benefits from employment protection reform strengthen. As jobs are created, unemployment declines, gets back to its pre-reform level - after less than a year-and ultimately falls further. This leads to higher GDP gains, which materialize fully roughly after two years. Real wages, however, remain permanently below their pre-reform levels (Table 2).

\footnotetext{
${ }^{34}$ The solid line denotes the benchmark calibration of monetary policy, the dot-dash combination denotes the more aggressive response to inflation, and dashes denote the more aggressive response to the GDP gap.

${ }^{35}$ The overall decline in marginal costs is small, however, because the costs of recruiting new workers increase due to the congestion externality in the labour market - i.e., the fact that firms posting a vacancy do not take into account its impact on overall labor market tightness, which in turn makes it harder for other firms to fill their vacancies.
} 
Responses to this reform are very similar across calibrations of the monetary policy rule, and policy responds to the reform by increasing the interest rate: Under all calibration of the policy rule, higher inflation ends up determining the direction of the policy response.

Unemployment Benefit Reform Figure 2 presents the impulse responses to a reduction in the unemployment benefit replacement rate. Responses are qualitatively comparable to the case of employment protection reform, but the effects of lower unemployment benefits are more favorable in the short term. This is essentially because lower unemployment benefits boost job creation but do not increase job destruction, unlike lower firing costs. This results in an immediate decline in unemployment - which also turns out to be ultimately more significant for a plausible calibration of the reforms. ${ }^{36}$

Consumption increases as a result of lower unemployment and higher income both in the short run and in the future. GDP also rises immediately. Despite the decline in marginal costs associated with lower wages, there is a small pick-up in CPI inflation in equilibrium, reflecting higher aggregate demand and higher prices of imported goods. The current account improves slightly as the decline in the relative price of home goods induces expenditure switching toward them and away from foreign goods. Again, the interest rate is increase. Over time, the gains from unemployment benefit reform increase: Unemployment continues to decline and GDP rises further as jobs are created, with the full effects being felt about two years after the reform. As with employment protection reform, real wages remain durably below their pre-reform levels, and there are very small differences across calibrations of monetary policy. ${ }^{37}$

Activation Policy Reform Figure 3 presents the responses to ALMP reform, which are qualitatively comparable to those of a benefit replacement rate cut. Strengthening activation policies through enhanced matching efficiency and lower utility value of unemployment boosts job creation in the short run without affecting job destruction. As a result, there is an immediate and large decline in unemployment, which continues until about two years after the reform. Consumption and GDP increase as a result of lower unemployment and higher income both on impact and in the future. Wages decline and remain persistently below their pre-reform levels, putting downward

\footnotetext{
${ }^{36}$ Sensitivity analysis not reported here also suggests that unemployment benefit reform has a larger long-term impact on GDP than employment protection reform, with product market reform yielding the largest gain.

${ }^{37} \mathrm{~A}$ word of caution is warranted in drawing strong conclusions on the effects of unemployment benefit reforms, which inevitably rely on specific modeling choices. In particular, we assume that worker productivity is unaffected by the generosity of the system. Assuming that more generous unemployment benefits encourage the development of high-risk but high-productivity activities, as in Acemoglu and Shimer (2000), could deliver different results.
} 
pressure on the price of home goods. Nevertheless, higher aggregate demand and higher prices of imported goods push inflation somewhat higher, and the current account strengthens slightly as a result of the decline in the relative price of home goods. Again, the interest rate rises and there are very small differences across monetary policy calibrations. ${ }^{38}$

\section{Product Market Reform}

Figure 4 presents the responses to product market deregulation. Consumption declines in the short term, because profitable investment opportunities in new firms induce households to save more, offsetting the positive impact of higher expected future income on current consumption. Nevertheless, consumption falls less than it would in a closed economy as households borrow from abroad, resulting in a sizable weakening of the current account. ${ }^{39}$ This is consistent with results in Cacciatore, Fiori, and Ghironi (forthcoming, a and b) and injects some caution in naive readings of results in existing literature. For instance, Corsetti, Martin, and Pesenti (2013) correctly point out the benefit of easier business creation for long-run net foreign debt sustainability, but they do so in a static model. A dynamic model such as ours highlights that easier business creation can plausibly lead to a worsened current account at least for some time. ${ }^{40}$

Firm entry boosts job creation, but the fall in consumption reduces aggregate demand. On impact these two effects offset each other, leaving unemployment essentially unchanged under the benchmark monetary policy rule. As the new firms that entered the market start producing, fiercer competition erodes the market share of incumbents, who downsize. Unemployment temporarily rises, as job destruction initially dominates job creation.

Product market reform increases the marginal production costs of incumbents for two reasons: (i) Only the more productive workers keep their jobs as downsizing firms immediately lay off less productive workers, and because remaining workers are better paid - even when accounting for their

\footnotetext{
${ }^{38}$ Note that improvements in matching efficiency alone could theoretically increase rather than reduce unemployment. This is because enhanced matching efficiency does not only facilitate new hires, but also encourages firms to lay off less productive workers by reducing the expected cost of posting vacancies to replace them. This can result in greater labor market turnover in equilibrium.

${ }^{39}$ In Cacciatore, Duval, Fiori, and Ghironi, (2015), we make a start at introducing financial frictions (other than incomplete international financial markets) in our analysis of structural reforms, and we show that lack of access to international lending can amplify the costs of adjustment to product market deregulation: Under financial autarky, domestic households must reduce consumption and investment in physical capital by more to finance product creation, leading to lower aggregate demand in the short run. Andrés, Arce, and Thomas (2014) explore the consequences of financial frictions in the form of collateral constraints in their analysis of markup cuts.

${ }^{40}$ This worsening of the current account also contrasts with the immediate improvement from a "reduced-form" reform of the product market via exogenously slashing markups (as in Eggertsson, Ferrero, and Raffo, 2014) that would automatically lead to terms of trade depreciation.
} 
higher productivity-, marginal labor costs rise; (ii) Current and expected firing costs (which are a component of the marginal production cost) increase because of the higher probability of laying off existing workers. Higher production costs push the price of domestic goods higher, albeit less than proportionally due to price stickiness, resulting in temporarily lower markups. ${ }^{41}$ The relative price of home goods (i.e., the terms of trade) rises. ${ }^{42}$ Reflecting productivity gains, GDP increases along the transition towards its new long-run level.

Upward pressure on domestic goods prices induces the central bank to raise the interest rate, so that CPI inflation changes only modestly in equilibrium - with some variation across different monetary policy calibrations, however. Higher domestic goods prices trigger substitution away from home goods toward foreign ones, further weakening the current account.

Over time, producer entry boosts job creation. Unemployment declines and eventually falls below its pre-reform level, but this process is slow. Along this process, wages and consumption increase. It takes longer to reach the new steady state after product market reform than after labor market reforms, however, though the long-term gains from product market reform are also larger (see Table 2 for long-run effects).

\section{Interactions across Market Policies and Reform Packages}

The effects of structural reform in one area depend in part on existing policy and institutional settings in other areas. Most importantly, the dynamics of the economy in the aftermath of product market reform are smoother if the labor market is "flexible" - as measured here by less stringent employment protection and lower unemployment benefits. ${ }^{43}$ We illustrate this in Figure 5 . When entry barriers are lowered, new job vacancies are filled more quickly and laid-off workers find new jobs more rapidly in a flexible labor market. However, the long-run gains from product market reform are smaller if labor markets are flexible (Table 2). This is because employment is higher to

\footnotetext{
${ }^{41}$ Increased input costs are not uncommon in the handful of DSGE model-based simulations of the dynamic effects of product market reforms (see De Bandt and Vigna, 2008, or Everaert and Schule, 2008, for reforms in the tradable sector). In the model used here, and unlike in these papers, the inflationary impact of higher input costs is not dominated by the deflationary effect of lower markups. This is partly because product market reforms are modeled as a decline in entry costs rather than an exogenous markup cut-indeed while markups vary during the transition, they remain unchanged in the steady state of our model. Alternative model specifications (not reported here) with translog preferences and endogenous flexible-price markups that decline with the number of firms did not alter this finding, i.e., the price of domestic goods still increases in the wake of a decline in firm entry barriers.

${ }^{42}$ As noted above, this contrasts with the implications of exogenous price markup cuts and suggests that the benefits of product market reforms do not accrue via improved competitiveness, at least for some time.

${ }^{43}$ ALMP reforms are excluded from the simulations in this section because of the more arbitrary choice of policy parameter changes they entail. Results are qualitatively unaffected by this exclusion. In particular, results are qualitatively similar if the definition of a flexible labor market also includes higher matching efficiency and lower home production.
} 
begin with, so that reducing barriers to firm entry leads to a tighter labor market -i.e., to higher matching frictions-, lower profitability of firm entry, and, ultimately, a smaller number of new firms. Likewise, the long-run gains from reforms of employment protection, unemployment benefits, and activation are smaller if product markets are more flexible (Table 2), although the stringency of product market regulation does not significantly affect the short-term effects of these labor market reforms, because the latter do not have much impact on firm dynamics (results available on request). These results imply that there is long-run substitutability (rather than complementarity) between labor and product market reforms, i.e., a combination of both yields smaller gains than the sum of the effects of each of them undertaken in isolation. ${ }^{44}$

Although substitutability between product and labor market reforms mitigates the long-run gains from joint reforms of both markets, a broad reform package is still highly beneficial. This is because it does not only deliver larger long-term gains than individual reforms (Table 2), but also smooths short-term dynamics and speeds up the transition to the new steady state, as illustrated in Figure 6. A combination of product market, employment protection, and unemployment benefit reforms boosts GDP, employment, and wages immediately, in contrast with the effects of some of these reforms in isolation. In particular, reducing entry barriers in product markets in parallel to labor market reforms reverses the wages losses that would result from the latter alone. Likewise, unemployment benefit reform reverses the short-term rise in unemployment that would otherwise be associated with employment protection and product market reforms. More broadly, compared with individual reforms, a broad package yields a larger income gain, the expectation of which immediately boosts aggregate demand and job creation-although this effect is not sufficiently large to prevent some small short-term decline in consumption associated with product market reform. ${ }^{45}$

\section{The Role of Monetary Policy}

Despite some transition costs in some cases, none of the reforms considered in the previous sections has deflationary effects that would call for interest rate cuts. Therefore, the model suggests that the ZLB constraint may not be an obstacle to the implementation of structural reforms in practice. ${ }^{46}$

\footnotetext{
${ }^{44}$ This point remains empirically debated. Fiori et al. (2012) find support for this theoretical prediction. Bassanini and Duval (2009) instead find evidence of complementarity across a broad range of product and labor market reforms.

${ }^{45}$ Note that the reform package still implies a worsening of the current account for over two years, as the home country borrows to finance increased firm creation.

${ }^{46}$ This would no longer be the case if reforms instead turned out to have deflationary effects, as in Eggertsson (2010), where supply-side policies are assumed to boost only current supply, or Eggertsson, Ferrero, and Raffo (2014)
} 
As noted above, differences in the characteristics of monetary policy, conducted by means of simple, empirically relevant rules, do not appear to play a major role for the dynamic adjustment to labor market reforms (Figures 1-3). This is essentially because transition dynamics are largely driven by firm and consumer expectations of the long-run effects of reforms, which do not depend on the conduct of monetary policy as specified in this paper. As a result, different monetary policy rules do not substantially alter marginal cost dynamics along the transition path, generating only small differences for markups and domestic producer prices. ${ }^{47}$ There are slight differences across monetary policy scenarios, however. In particular, a rule that assigns greater weight to inflation achieves somewhat quicker stabilization of price markups (for employment protection, unemployment, benefit and activation policy reforms). These findings also hold, but are quantitatively stronger, in the case of product market reform, because this has larger effects on marginal costs, price markups, and domestic producer prices (see Figure 4 and Figure 5 for similar findings when a broad package of product and labor market reforms is implemented). A central bank that responds more aggressively to inflation dampens the decline in price markups at the cost of higher and more persistent unemployment. ${ }^{48}$

Finally, short-run gains from labor market reforms are only marginally smaller if the reforming country belongs to a large monetary union than if it has a flexible exchange rate regime. Labor market reforms slightly reduce marginal costs and domestic producer prices (results not reported). As a result, the real interest rate tends to be somewhat higher than under a flexible exchange rate if, as in a large monetary union, the domestic central bank cannot respond to the shock imparted by the reform. Aggregate demand and the short-run gains in employment and GDP are then slightly smaller, and it takes a bit longer for the full benefits of labor market reforms to materialize. For product markets, by contrast, since a decline in barriers to firm entry raises domestic producer costs and prices, a fixed exchange rate implies a lower real interest rate in the short run. This results in short-run gains in GDP and employment (see Figure 7). These results suggest that inability of monetary policy to deliver interest rate cuts in the aftermath of reforms because of the ZLB may not be an obstacle to reform implementation, in contrast to Eggertsson, Ferrero, and Raffo (2014)

and other recent studies, where reforms are modeled as markup cuts that have an immediate negative effect on prices.

${ }^{47}$ Cacciatore, Fiori, and Ghironi (forthcoming, a) study optimal monetary policy following market deregulation in a monetary union of comparable-size countries. They show that the transition adjustment implied by the optimal policy differs from the one implied by the type of simple policy rule studied here. The reason is that optimal policy implies an endogenous inflation target that changes following market deregulation, unlike the simple rules of this paper, with consequences for the dynamic adjustment to reforms.

${ }^{48}$ Cacciatore, Fiori, and Ghironi (forthcoming, a) show that a policy of zero producer price inflation is suboptimal in response to market reforms. In general, the optimal policy must strike a balance between minimizing price markup and unemployment fluctuations relative to their (efficient) equilibrium levels. 
and other studies that use the same approach to modeling reforms.

\section{Conclusions}

This paper studied the consequences of product and labor market reforms in a New Keynesian, small open economy models with endogenous producer entry subject to sunk costs and labor market frictions. We showed that the benefits of reforms take time to materialize, and some reforms can entail short-run transition costs. However, our results suggest that reforms do not impart significant deflationary pressure. Therefore, concerns about the zero lower bound on interest rates (or inability to use independent monetary policy in a monetary union) may not be stumbling blocks on the way to increased market flexibility.

\section{References}

[1] Acemoglu, D. and R. Shimer (2000), "Productivity Gains from Unemployment Insurance," European Economic Review: 44: 1195-1224.

[2] Andolfatto, D. (1996): "Business Cycles and Labor-Market Search," American Economic Review 86: 112-132.

[3] Andrés, J., Ó. Arce, and C. Thomas (2014): "Structural Reforms in a Debt Overhang," mimeo, University of Valencia and Banco de España.

[4] Arpaia, A., R. Werner, J. Varga, and J. Veld (2007): "Quantitative Assessment of Structural Reforms: Modeling the Lisbon Strategy," European Commission Economic Paper 282.

[5] Bassanini, A., and R. Duval (2009): "Unemployment, Institutions, and Reform Complementarities: Re-assessing the Aggregate Evidence for OECD Countries," Oxford Review of Economic Policy 25: 40-59.

[6] Benigno, P. (2009): "Price Stability with Imperfect Financial Integration," Journal of Money, Credit and Banking 41: 121-149.

[7] Bilbiie, F. O., F. Ghironi, and M. J. Melitz (2008): "Monetary Policy and Business Cycles with Endogenous Entry and Product Variety," in Acemoglu, D., K. S. Rogoff, and M. Woodford, eds., NBER Macroeconomics Annual 200\%, University of Chicago Press, Chicago, IL, pp. 299353.

[8] Bilbiie, F. O., F. Ghironi, and M. J. Melitz (2012): "Endogenous Entry, Product Variety, and Business Cycles," Journal of Political Economy 120: 304-345.

[9] Black, D. A., J. A Smith, M. C. Berger, and J. N Brett (2003): "Is the Threat of Reemployment Services More Effective than the Services Themselves? Evidence from a Random Assignment in the UI System," American Economic Review 93: 1313-1327. 
[10] Blanchard, O. J., and F. Giavazzi (2003): "Macroeconomic Effects of Regulation and Deregulation in Goods and Labor Markets," Quarterly Journal of Economics 118: 879-907.

[11] Bouis, R., O. Causa, L. Demmou, R. Duval, and A. Zdzienicka (2012): "The Short-Term Effects of Structural Reforms: An Empirical Analysis," OECD Economics Department Working Paper 949 .

[12] Broda, C., and D. E. Weinstein (2010): "Product Creation and Destruction: Evidence and Price Implications," American Economic Review 100: 691-723.

[13] Cacciatore, M., R. Duval, G. Fiori, and F. Ghironi (2015): "Market Reforms in the Time of Imbalance," mimeo, HEC Montreal, North Carolina State University, and University of Washington.

[14] Cacciatore, M., and G. Fiori (forthcoming): "Macroeconomic Effects of Goods and Labor Market Deregulation", mimeo, Review of Economic Dynamics.

[15] Cacciatore, M., G. Fiori, and F. Ghironi (forthcoming, a): "Market Deregulation and Optimal Monetary Policy in a Monetary Union," Journal of International Economics.

[16] Cacciatore, M., G. Fiori, and F. Ghironi (forthcoming, b): "“The Domestic and International Effects of Euro Area Market Reforms," Research in Economics.

[17] Cacciatore, M., F. Ghironi, and V. Stebunovs (2015): "The Domestic and International Effects of Interstate U.S. Banking," Journal of International Economics 95: 171-187.

[18] Cacciatore, M., F. Ghironi, and S. J. Turnovsky (2014): "Inflation Targeting and Economic Reforms in New Zealand," prepared for the RBNZ-IJCB Conference on Reflections on 25 Years of Inflation Targeting, Wellington, NZ.

[19] Campolmi, A., and E. Faia (2011): "Labor Market Institutions and Inflation Volatility in the Euro Area," Journal of Economic Dynamics and Control 35: 793-812.

[20] Corsetti, G., P. Martin, and P. Pesenti (2013): "Varieties and the Transfer Problem," Journal of International Economics 89: 1-12.

[21] De Bandt, O., and O. Vigna (2008): "The Macroeconomic Impact of Structural Reforms," Banque de France Bulletin Digest 0169.

[22] den Haan, W. J., G. Ramey, and J. Watson (2000): "Job Destruction and Propagation of Shocks," American Economic Review, 90: 482-498.

[23] Diamond, P. A. (1982a): "Wage Determination and Efficiency in Search Equilibrium," Review of Economic Studies 49: 217-227.

[24] Diamond, P. A. (1982b): "Aggregate Demand Management in Search Equilibrium," Journal of Political Economy 90: 881-894.

[25] Ebell, M., and C. Haefke (2009): "Product Market Deregulation and the U.S. Employment Miracle," Review of Economic Dynamics 12: 678-695.

[26] Eggertsson, G. (2010): "The Paradox of Toil," Federal Reserve Bank of New York Staff Report 433. 
[27] Eggertsson, G., A. Ferrero, and A. Raffo (2014): "Can Structural Reforms Help Europe?" Journal of Monetary Economics 61: 2-22.

[28] ECB (2002): "Labor Market Mismatches in the Euro Area Countries," European Central Bank.

[29] Everaert, L., and W. Schule (2008): "Why It Pays to Synchronize Structural Reforms in the Euro Area across Markets and Countries," IMF Staff Papers 55.

[30] Feenstra, R. C. (1994): "New Product Varieties and the Measurement of International Prices," American Economic Review 84: 157-177.

[31] Fernández-Villaverde, J., P. Guerrón-Quintana, and J. Rubio-Ramírez (2011): "Supply-Side Policies and the Zero Lower Bound," NBER Working Paper 17543.

[32] Fernandez, R., Rodrik, D. (1991): "Resistance to Reform: Status Quo Bias in the Presence of Individual-Specific Uncertainty", American Economic Review, 81: 1146-1155.

[33] Fiori, G., G. Nicoletti, S. Scarpetta, and F. Schiantarelli (2012): "Employment Outcomes and the Interaction between Product and Labor Market Deregulation: Are They Substitutes or Complements?" Economic Journal 122: F79-F104.

[34] Geerdsen, L. P., and A. Holms (2007): "Duration of UI Periods and the Perceived Threat Effect from Labour Market Programmes," Labour Economics 14: 639-652.

[35] Ghironi, F., and M. J. Melitz (2005): "International Trade and Macroeconomic Dynamics with Heterogeneous Firms," Quarterly Journal of Economics 120: 865-915.

[36] Gomes, S., P. Jacquinot, M. Mohr, and M. Pisani (2011): "Structural Reforms and Macroeconomic Performance in the Euro Area Countries: A Model-based Assessment," ECB Working Paper 1323.

[37] Hall, R. E. (2005): "Job Loss, Job Finding, and Unemployment in the U.S. Economy Over the Past Fifty Years," NBER WP 11678.

[38] Hobijn, B., and A. Sahin (2008): “Unemployment Dynamics in the OECD," NBER WP 14617.

[39] Hobza, A., and G. Mourre (2010): "Quantifying the Potential Macroeconomic Effects of the Europe 2020 Strategy: Stylized Scenarios," European Commission Economic Paper 424.

[40] IMF (2010): "G-20 Mutual Assessment Process-Alternative Policy Scenarios," Report by the IMF Staff.

[41] Juilliard, M. (1996): "Dynare : A Program for the Resolution and Simulation of Dynamic Models with Forward Variables through the Use of a Relaxation Algorithm," CEPREMAP WP 9602.

[42] Kluve, J. (2010): "The Effectiveness of European Active Labour Market Programmes," Labour Economics 17: 904-918.

[43] Krause, M. U., and T. A. Lubik (2007): "The (Ir)Relevance of Real Wage Rigidity in the New Keynesian Model with Search Frictions," Journal of Monetary Economics 54: 706-727. 
[44] Krusell, P., T. Mukoyama, and A. Sahin (2010): "Labour-Market Matching with Precautionary Savings and Aggregate Fluctuations," Review of Economic Studies, 77: 1477-1507.

[45] Laffargue, J.-P. (1990): "Résolution d'un Modèle Macroéconomique avec Anticipations Rationnelles," Annales d'Economie et de Statistique 17: 97-119.

[46] Langot, F., L. Patureau, and T. Sopraseuth (2014): "Fiscal Devaluation and Structural Gaps," mimeo, Université du Mans, Université Paris-Dauphine, and Université de Cergy-Pontoise.

[47] Nakajima, M. (2012): "Business Cycles in the Equilibrium Model of Labor Market Search and Self-Insurance," International Economic Review, 53: 399-432.

[48] Merz, M. (1995): "Search in the Labor Market and the Real Business Cycle," Journal of Monetary Economics 36: 269-300.

[49] Mortensen, D. T., and C. A. Pissarides (1994): "Job Creation and Job Destruction in the Theory of Unemployment," Review of Economic Studies 61: 397-415.

[50] Mortensen, D. T., and C. A. Pissarides (2002): "Taxes, Subsidies and Equilibrium Labor Market Outcomes," CEP Discussion Papers dp0519, Centre for Economic Performance, LSE.

[51] OECD (2004): "Employment Outlook," Organisation for Economic Co-operation and Development.

[52] OECD (2005): "Taking Stock of Structural Policies in OECD Countries," Economic Policy Reforms: Going for Growth, Organisation for Economic Co-operation and Development.

[53] OECD (2012): "Structural Reforms in Times of Crisis," Economic Policy Reforms: Going for Growth, Organisation for Economic Co-operation and Development.

[54] Olson, M. (1965): "The Logic of Collective Action: Public Goods and the Theory of Groups," Harvard University Press, Cambridge MA.

[55] Petrongolo, B., and C. A. Pissarides (2006): "Scale Effects in Markets with Search," Economic Journal 116: 21-44.

[56] Pissarides, C. A. (2003): "Company Start-up Costs and Employment," in Aghion, P., R. Frydman, J. Stiglitz, and M. Woodford, eds., Knowledge, Information, and Expectations in Modern Macroeconomics: In Honor of Edmund S. Phelps, Princeton University Press, Princeton, NJ, pp. 309-325.

[57] Rotemberg, J. J. (1982): “Monopolistic Price Adjustment and Aggregate Output," Review of Economic Studies 49: 517-531.

[58] Saint-Paul, G. (2000): "The Political Economy of Labor Market Institutions," Oxford University Press, Oxford

[59] Shimer, R. (2005): "The Cyclical Behavior of Equilibrium Unemployment and Vacancies," American Economic Review 95: 25-49.

[60] Thomas, C., and F. Zanetti (2009): "Labor Market Reform and Price Stability: An Application to the Euro Area," Journal of Monetary Economics 56: 885-899. 
[61] Turnovsky, S. J. (1985): "Domestic and Foreign Disturbances in an Optimizing Model of Exchange Rate Determination," Journal of International Money and Finance 4: 151-171.

[62] Weber, A. (2000): "Vacancy Durations-A Model for Employer's Search," Applied Economics 32: 1069-1075.

[63] Woodford, M. (2003): Interest and Prices: Foundations of a Theory of Monetary Policy, Princeton University Press, Princeton, NJ. 
TABLE 1: CALIBRATION

\begin{tabular}{llll}
\hline \hline Variety elasticity of substitution & $\theta=11$ & Unemployment benefit & $b=0.885$ \\
\hline Risk aversion & $\gamma=2$ & Firing costs & $F=0.109$ \\
\hline Home and Foreign Goods Substitutability & $\phi=1.5$ & Home Bias & $\alpha=0.2$ \\
\hline Habits persistence & $h=0.6$ & Price Adjustment Cost & $\nu=80$ \\
\hline Discount factor & $\beta=0.99$ & Matching function elasticity & $\varepsilon=0.6$ \\
\hline Bond adjustment cost & $\tau=0.004$ & Workers' bargaining power & $\eta=0.6$ \\
\hline Exogenous separation rate & $\lambda^{S}=0.0340$ & Home production & $h_{P}=0.132$ \\
\hline Regulation entry cost & $f_{r}=0.865$ & Matching efficiency & $\chi=0.593$ \\
\hline Plant exit & $\delta=0.021$ & Vacancy cost & $k=0.089$ \\
\hline Real wage rigidity & $\varrho=0.7$ & Lognormal Shape & $\sigma_{z_{i}}=0.35$ \\
\hline Historical Policy, Interest Rate Smoothing & $\varrho_{i}=0.8$ & Historical Policy, Inflation Response & $\varrho_{\pi}=2$ \\
\hline Historical Policy, GDP Gap Response & $\varrho_{Y}=0.2$ & & \\
\hline \hline
\end{tabular}




\begin{tabular}{|c|c|c|c|c|}
\hline & $\begin{array}{l}\text { Consumption } \\
\text { (in \%) }\end{array}$ & $\begin{array}{l}\text { Unemployment } \\
\text { (in pct points) }\end{array}$ & $\begin{array}{l}\text { Output } \\
\text { (in \%) }\end{array}$ & $\begin{array}{c}\text { Real Wage } \\
\text { (in \%) }\end{array}$ \\
\hline Decline in barriers to entry & 6.9 & -0.8 & 7.1 & 6.2 \\
\hline Relaxation of job protection & 0.3 & -0.5 & 1 & -0.3 \\
\hline $\begin{array}{l}\text { Reduction in unemployment benefit } \\
\text { replacement rate }\end{array}$ & 2.5 & -4.0 & 2.9 & -1.1 \\
\hline Strengthening of activation policy & 1.9 & -3.7 & 3.4 & -0.5 \\
\hline Reform package & 9.5 & -5.2 & 10.7 & 4.6 \\
\hline $\begin{array}{l}\text { Decline in barriers to entry } \\
\text { (in "flexible"labour markets) }\end{array}$ & 6.4 & -0.2 & 6.6 & 6.4 \\
\hline $\begin{array}{l}\text { Relaxation of job protection } \\
\text { (in "flexible" product markets) }\end{array}$ & 0.2 & -0.5 & 1 & -0.3 \\
\hline $\begin{array}{l}\text { Reduction in unemployment benefit } \\
\text { replacement rate (in "flexible" product markets) }\end{array}$ & 2.1 & -3.4 & 2.4 & -1 \\
\hline
\end{tabular}



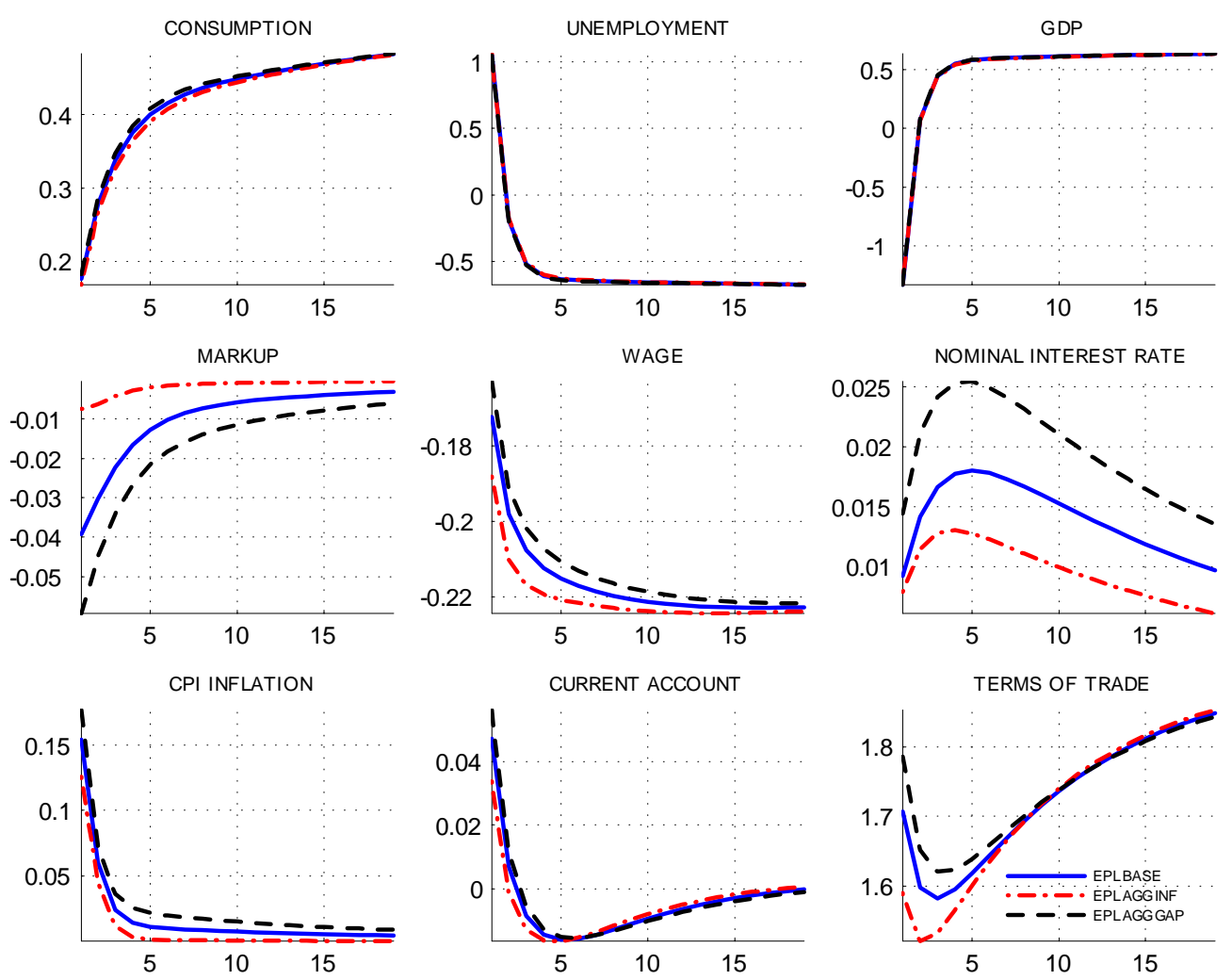

Figure 1. Employment protection reform.
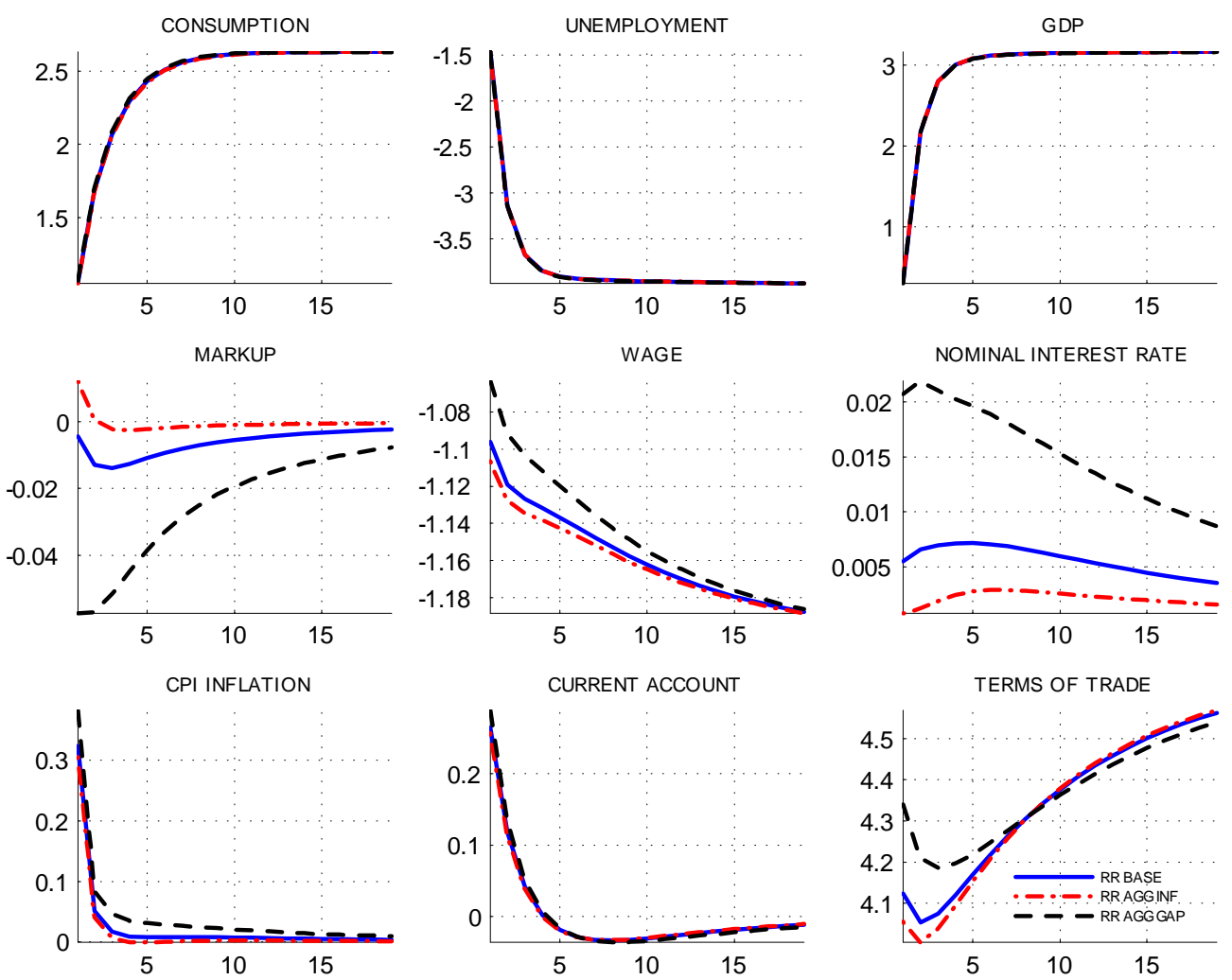

Figure 2. Unemployment benefit reform. 

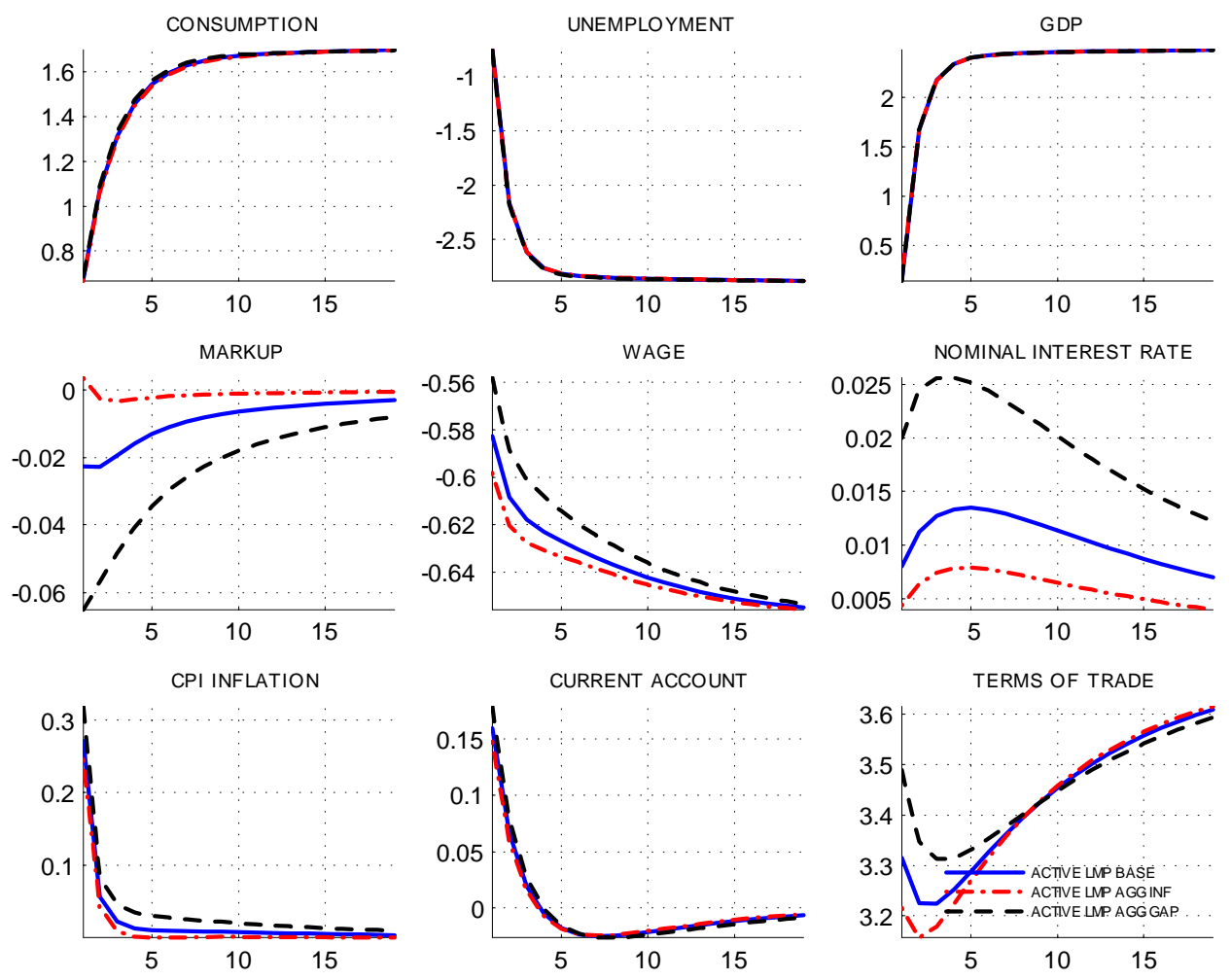

Figure 3. Active policy reform.
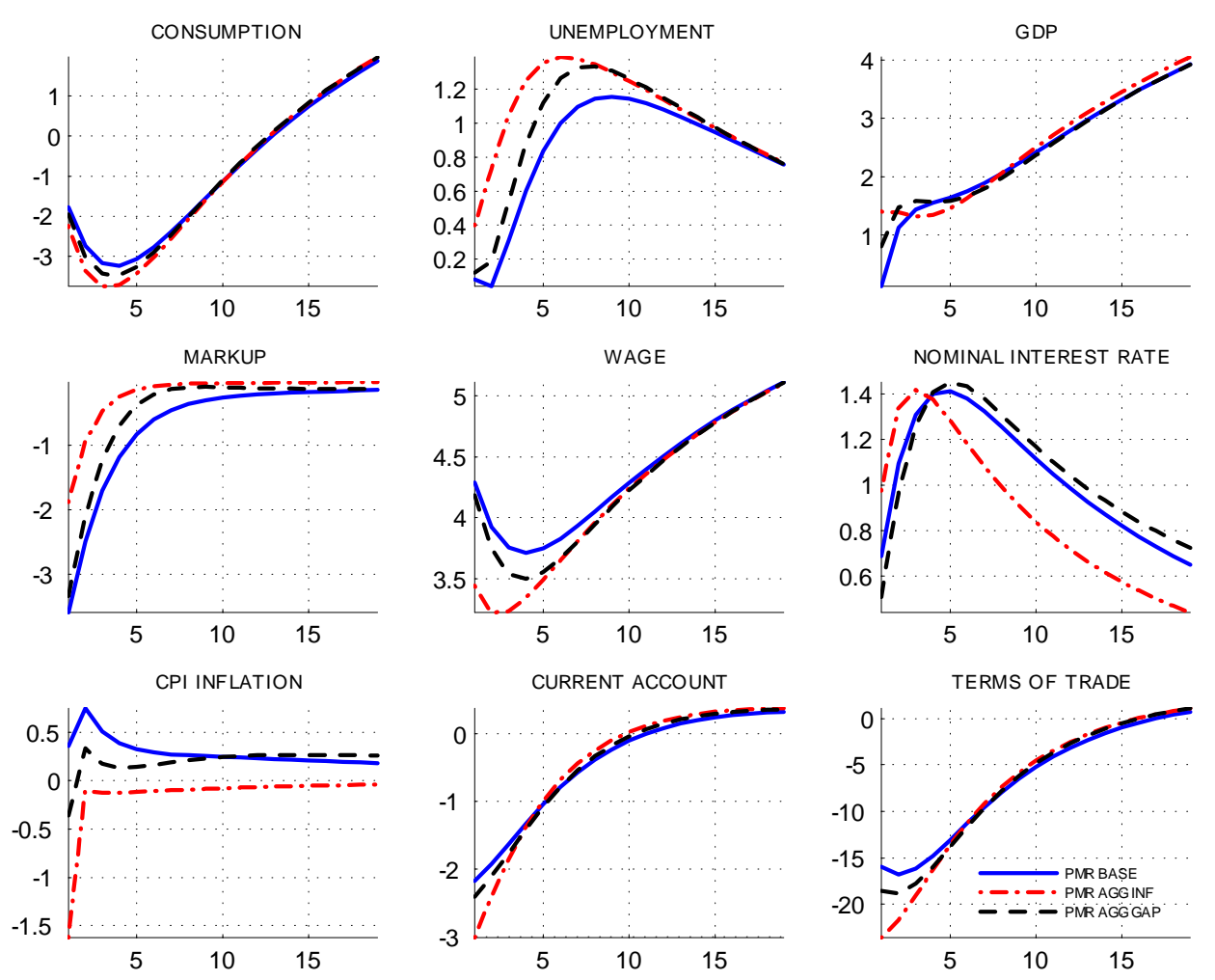

Figure 4. Product market reform. 

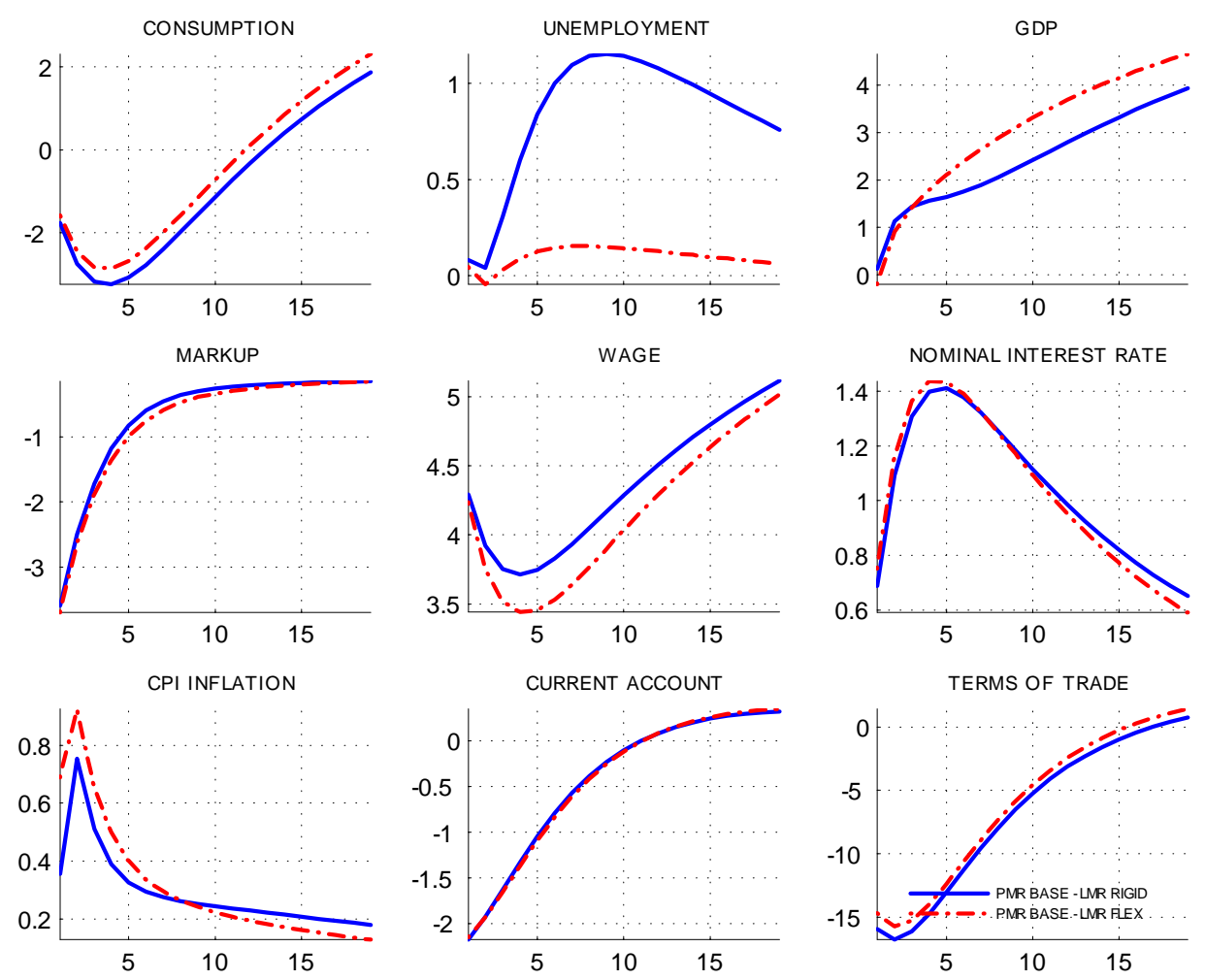

Figure 5. Product market reform in a "flexible" vs. "rigid" labor market (under the benchmark policy rule).
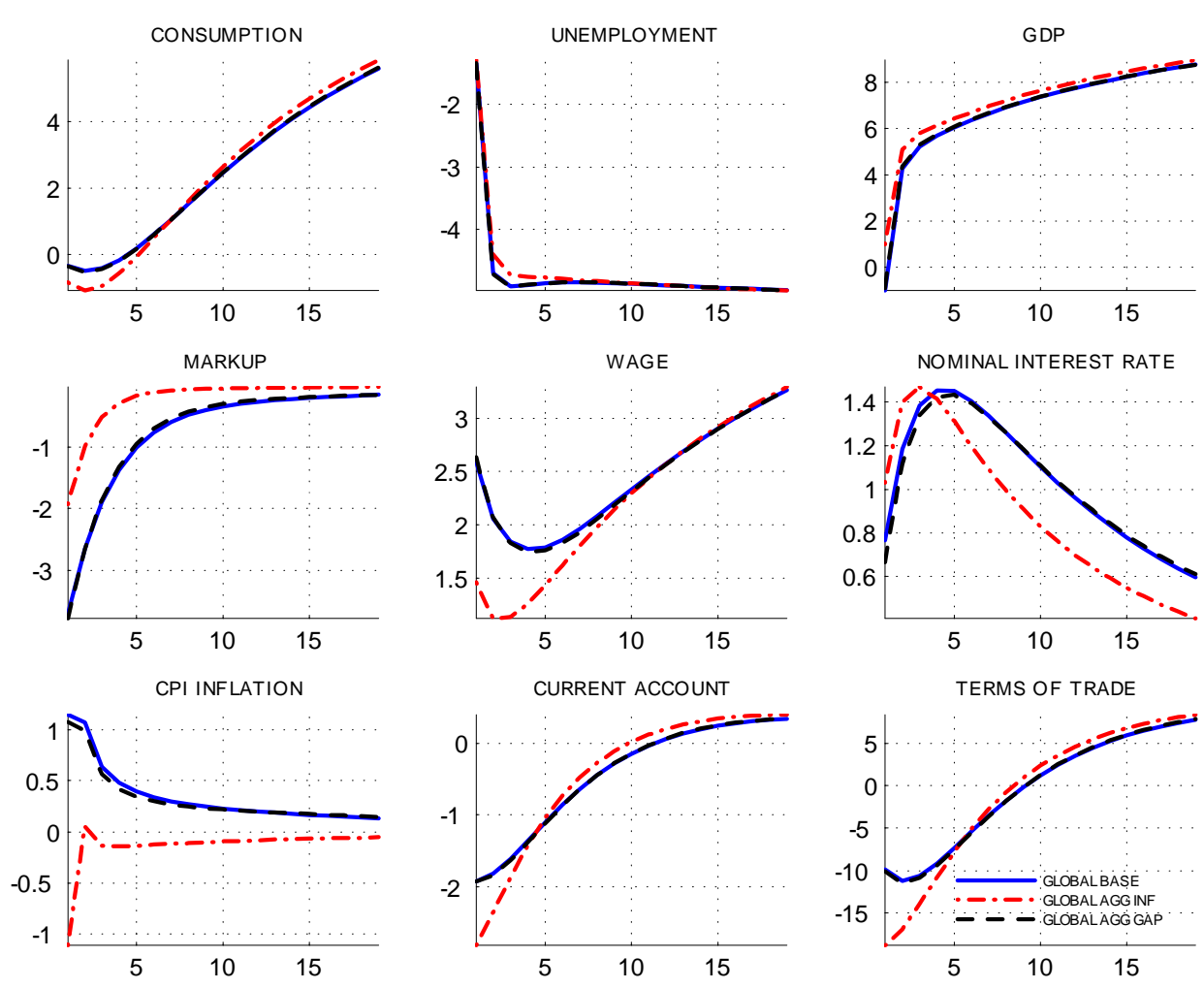

Figure 6. Reform package. 

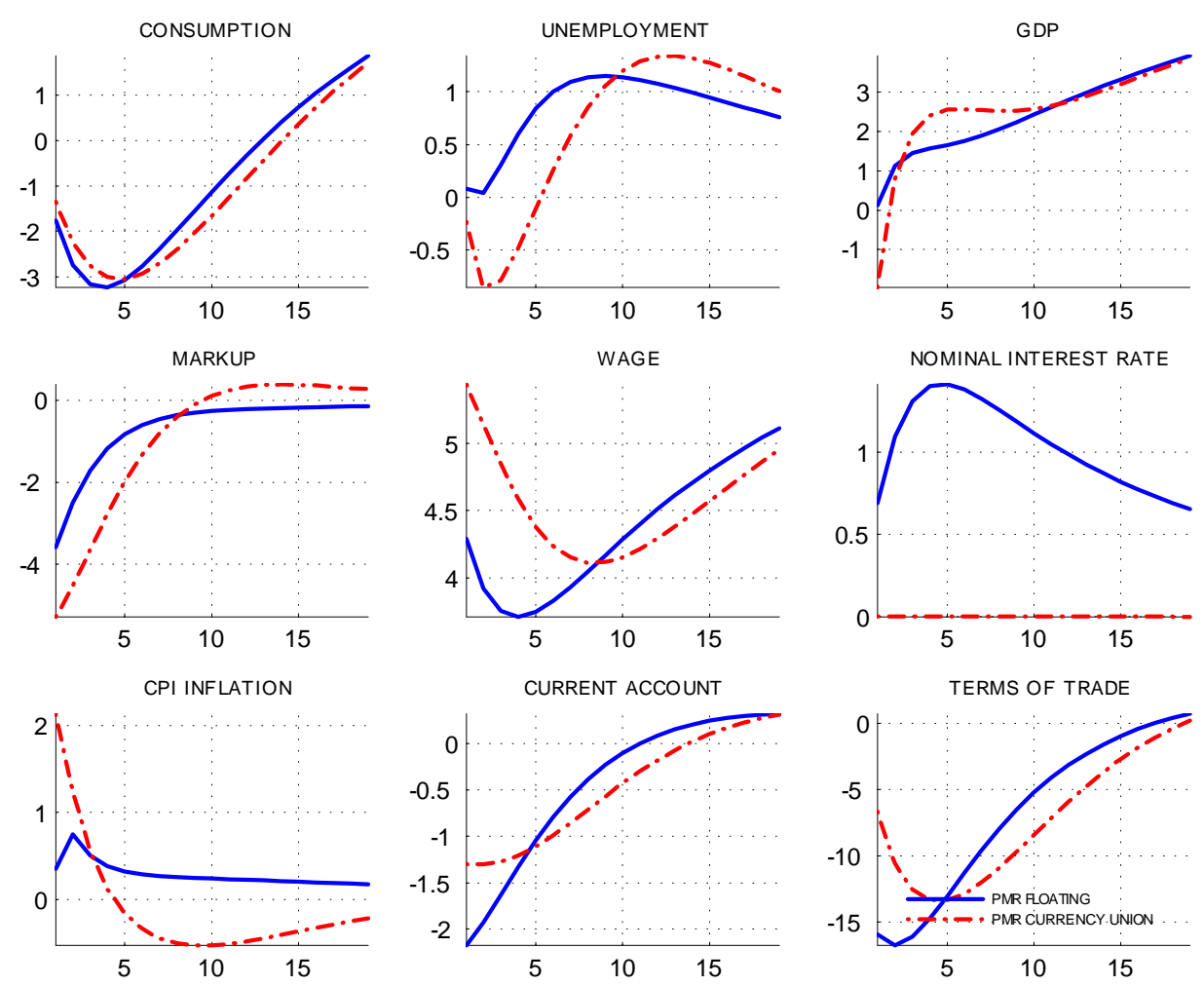

Figure 7. Product market reform in a currency area versus floating exchange rate. 